\title{
The Effect of Audit Committee's Characteristics on the Audit Report Timeliness: Empirical Evidence from the $\mathrm{Uk}^{1}$
}

\author{
Dr. Laila Mohamed Alshawdfy \\ Aladwey \\ Lecturer in Accounting, Faculty \\ of commerce, Tanta University \\ laila.eladawi@commerce.tanta.edu.eg
}

\author{
Dr. Adel Hassan Elgharbawy
}

Lecturer in Accounting and Information

System Department, College of Business and Economics, Qatar University

adelelgharbawy@gmail.com

\begin{abstract}
This paper examines the association between the attributes of the audit committees (ACs) and the audit report timeliness for UK FTSE350 companies over the period 2017 to 2019. In particular, we investigate the impact of AC's attributes, namely, independence, gender, financial expertise, activity and size; as prescribed by the UK Corporate Governance code (2018) on the audit report lag (ARL). To this end, we employ the OLS regression with robust standard errors based on 633 firm-year observations. Our results indicate that AC's independence and meeting frequency are associated with a reduction in audit report delay. However, the results also indicate that AC's gender, financial expertise and size do not influence the audit report timeliness. More interestingly, the UK listed companies, which issue their annual reports during the busy reporting period tend to have longer ARL. In contrast, the high audit fees are significantly associated with shorter ARL. Contrary to the propositions of the critical mass theory, additional analysis reveals that high representation of female directors in ACs would deter the financial reporting timeliness, since it is associated with longer ARL. Our results are also robust for alternate measures for ACs' attributes of size, activity and expertise. The findings of our study highlight the importance of ACs, as an internal governance mechanism, in enhancing the timeliness and the quality of companies' financial reporting. It accentuates the role of independent director, as well as the ACs' meeting, in alleviating any disputes and settling any issue that might hinder the external auditors to release timelier audit report. Our findings also direct the attention of the $U K$ regulators to the importance of providing a clearer definition of the financial expertise required by ACs' members. In addition, our results also direct the attention of the UK companies to the importance of choosing the female directors' members in ACs based on their qualification and expertise, rather than their mere representation to satisfy the UKCG recommendation.
\end{abstract}

Keywords: Audit committees' attributes, Audit report lag, Corporate Governance, FTSE 350, $U K$.

${ }^{1}$ Received in 31 October 2021, accepted in 9 November 2021. 


\section{I- INTR ODUCTION}

The introduction of more robust governance mechanisms in the last twenty-five years all over the world come as a response to a number of corporate failure scandals of prestigious companies that suffered from poor or non-presence of governance structure (Ghafran and O'Sullivan, 2017). The Sarbanes-Oxley Act in the USA; the Corporate Law Economic Reform Program in Australia; and the Combined Code in the UK came to enhance companies' governance structures and quality of financial reporting (Baatwah et al., 2019). Audit Committee (AC) is recognized as an internal governance mechanism committed to supervise, control and assist management in executing robust internal control, present fair financial reporting and monitoring the auditing process (Beasley et al., 2oro; Sun et al., 2oII; Oussii et al., 2019; Guidelines of Board Effectiveness, 2018).

$\mathrm{AC}$ is a subunit of the corporate board with a delegated authority to oversight the auditing and financial reporting related issues (Ghafran and O'Sullivan, 20I7; Bhuiyan and D'Costa, 2020). Timely release of financial information is an important aspect of companies' financial reporting and an important element for decision makers (Owusu-Ansah, 200o; Baatwah et al., 2019). FASB and IASB's conceptual frameworks recognize the timeliness of financial reporting, as an important attribute of accounting information, which means the availability of accounting information to stakeholders in the relevant time range before it loses its value to influence their decision. The time period it takes for auditors to release the audit report is recognized as the chief factor that determines the companies' timely financial reporting (Afify, 2009; Sultana et al., 2015).

Audit report lag (ARL) represents the period of time between the company's ending date of the fiscal year and the date of the issuance of auditing report (Habib et al., 2019; Bhuiyan \& D'Costa, 2020). Since it conveys the auditors' opinion regarding the management' fairness in preparing the financial statements, investors and other stakeholders may be more inclined to lessen the period of the audit report issuance (Habib et al., 2019). In addition, regulatory bodies and shareholders highly regard the importance of the timely and high-quality financial reporting, as a result of the dramatic fate of somehigh-profile companies (Sultana et al., 2015). Furthermore, the delay in the financial reporting may deter the earning's quality, lead to negative market reactions (Bamber et al., 1993, Chan et 
al., 2016), and increase the information asymmetry between management and investors in a manner that may badly affect the investment decisions (MohamadNor et al., 20I0).

Driven from the notion of the agency theory, both ACs and external auditors are perceived as agents of shareholders, hence examining the interactions between such parties would add some insights to audit quality (Velte, 2020). In addition, the agency theorists argue that well-constructed ACs effectively play its governance role of monitoring management' actions (Cohen et al., 2004), and external auditing is an important governance mechanism, since it helps in monitoring the management actions by providing an independent verification of credibility of corporate reporting (Habib et al., 2019). Sultana et al, 20I5 accentuates the importance of studying the factors that shorten the time taken by the external auditors to issue their audit report. In addition, in a meta-analysis of the main determinants of ARL, Durand (2019) calls for more research that examine the association between the attributes of audit committee and ARL, since this area is still obscure and provide mixed findings. Accordingly, this study corresponds to this call by examining the main determinants of ARL in relationship to the ACs' attributes, as prescribed by the UK Corporate Governance (CG) Code.

A review of the literature around the main determinants of ARL in relationship to the ACs' characteristics reveals the scarcity of research on this topic in the UK. Unlike Ghafran and Yasmin (2018) who examine the association between the expertise held by AC's chair in the UK, we are going to take a further step by examining the associations between the main attributes of ACs according to the UK CG code and the financial reporting timeliness as measured by ARL. In particular, we investigate the influence of ACs' independence, gender, expertise, activity and size on ARL for the UK FTSE 350 companies for the period from 2017 to 2019 .

Based on 633 firm year observations, the main results of this study can be summarized as follows. First, our results indicate that AC's independence and the AC's diligence are the main determinants of the ARL in the UK. In consistent with our predication, our results indicate a negative association between ACs' independence and meeting frequency with the lag period undertaken by the auditors to issue the audit report. Second, contrary to our expectations, our results 
find that ARL is not a function of the other ACs' attributes of gender diversity, financial expertise and size. Third, results suggest that the UK companies which issue their financial reports during the busy reporting season have longer ARL, and those how paid higher audit fees have shorter ARL. Further analysis indicates that the more female directors in ACs, the longer the ARL. In addition, robustness check using other proxies of ACs attributes confirms our main results.

Our paper contributes to the extant literature on ACs' governance and audit report timelines in three specific ways. First, our results provide empirical evidence to the impact of ACs' attributes in enhancing the timeliness of the financial reporting within the UK. Practically, our results would direct the UK companies to the prominent oversight role of independent non-executive in maintaining strong governance actions that facilitate the external auditors'work in a manner that shorten the audit reporting period. Second, our results stimulate the UK companies to give more careful considerations to their way to establish gender diversity in ACs. In this regard, this study indicates that the female directors' representation per se would not guarantee ACs' effectiveness in conducting its monitoring role over the financial reporting, rather the educational qualifications as well as the professional expertise of female directors may do. Third, our study refers to the obscure notion of the financial expertise need to be held by at least one member of ACs as recommended by the UK CG code. Our study, therefore, should be of interest to the UK regulatory bodies to clearly identify the concept of financial expertise that should be possessed by AC's members and to specifically itemize the strands of such experience whether from educational and/or professional perspectives.

The organization of this study can be summarized as follows. Section two demonstrates the background, the literature review and hypotheses development. The design of the research is outlined in section three. Section four summarizes the descriptive statistics and regression results. Section five presents the additional analysis. The last section includes discussion, conclusion, limitations and suggestion for future research. 


\section{BACKGROUND, LITERATURE REVIEW AND HYPOTHESES DEVELOPMENT}

This section starts with an overview of the evolution of ACs in UK, their roles and the prescribed qualitative attributes of their members. In addition, it reviews the literature around the main determinants of ARL in relationship to the main attributes of ACs and five main hypotheses are employed.

\section{I The Evolution of AC's Composition IN The UK}

The UK has a leading history of pursuing global standards that manage the way listed companies are governed (Ntim, 2015). UK CG code has undergone several developments beginning from the Cadbury Report published in 1992 to the most recent UK Code published in July 2018 by the Financial Reporting Council (FRC) I. The code specifies the standards of best practise for UK listed companies regarding the composition of board and its supporting committees, remuneration policies, shareholder relations, and accountability and audit. AC is a subunit within the contemporary companies that are authorized to supervise and review the auditing and financial reporting themes (Bhuiyan and D'Costa, 2020).

In 1992, the Cadbury report recommends UK listed companies to form their ACs as a critical move toward embracing CG standards (Cadbury, 1992). In this regard, the Cadbury report identifies that the effective $\mathrm{AC}$ is dependent on the appointment of qualified and trustful committee' chairman and the involvement of competent non-executive directors as committee' members (Cadbury, 1992). In addition, the report prescribes the AC's composition of to include only nonexecutive directors and to encompass at least three members (Cadbury, 1992,). The years after the Cadbury report's recommendation have witnessed the prevalence

of ACs in UK as evidenced by Higgs report published in 2002, where only one FTSE Ioo company and $15 \%$ of FTSE 350 did not form an audit committee at the time of this report (Higgs, 2003).

The combined code (2003)represents an incremental step in the AC's governance in UK that is enacted concurrently with the adoption of SOX act in the USA in 2002 upon the collapse of Enron company (Habbash et al., 2013; Ghafran and

${ }^{1}$ https://www.frc.org.uk/directors/corporate-governance-and-stewardship 
O'Sullivan, 2017). The Combined Code Guidance recommends UK listed companies to include at least three members of independent non-executive directors and suggests that the board' chairman should not be a member in the AC (Smith Report, 2003). Additionally, the code recommends the inclusion of at least one member with "recent and relevant financial experience" (Smith Report, 2003); and requires AC's members to meet at least three times a year (Smith Report, 2003).

Similarly, in 20I8, the UK CG code advocates the board of director to form an AC that comprises at least three non-executive directors that are recognised as independent or only two in the case of smaller companies (Financial Reporting Council, 2018) I. The CG code also recommends the exclusion of the board's chairman from the AC's membership and the inclusion of at least one financial expert. In addition, the code asserts that the AC's members need to demonstrate their proficiency and experience in the industrial sector of their companies Although the UK CG code did not stipulate the inclusion of certain percent of female directors within the audit committee, it advocates the gender diversity (Velte, 2018). That is, the criteria should utilize to appoint boards' members need to encourage the diversity in gender and other personal attributes (Financial Reporting Council, 20I8).

According to the UK CG code, among the key responsibilities of audit committees are the oversight of the integrity of financial reporting; settling the audit engagement and evaluate the effectiveness of the audit process subject to UK legislation (Financial Reporting Council, 2018). Accordingly, the AC gains a considerable attention within UK companies as it is perceived as a governance mechanism that enhance the quality of financial reporting (Al-Shaer et al., 2017). Furthermore, (Al-Shaer and Zaman, 2018) refer to the evolution of ACs's role within UK to encompass the oversight of risk and non-financial reporting, rather than merely concentrating on the financial aspects of the CG.

The UK is considered a unique setting to study the impact of the AC's attributes on the audit report timeliness, proxied by ARL for many reasons. First, there is no

${ }^{1}$ The CG code, 2018 defines smaller companies as any company that is listed below the FTSE 350 within the fiscal year before the reporting year. 
legislation that obligate the UK companies to form ACs, although the presence of $\mathrm{AC}$ is required by other countries' legislation Habbash et al. (2013). Second, the UK CG code prescribes rather than mandates the AC's attributes in relation to its size; independence; frequency of meeting; expertise level and gender diversity. Thus, subject to the voluntary nature of ACs in the UK; we aim at study the effect of the AC's attributes, as prescribed by UK CG code, on the ARL (Financial Reporting Council, 20I8).

\subsection{PREVIOUS RESEARCH AND HYPOTHESES}

Tracking the literature around the main determinants of ARL in relation to the ACs' attributes demonstrate mixed and contradicted results. As shown in Table I, there is non-consensus among researchers in relation to the main ACs' strands that may affect the ARL, as well as their direction of association. Similarly, both Durand (2019) and Habib et al., (2019) call for further research that investigate the different facets of ACs' governance on their effect on ARL. In replying to this research call, five specific aspects of ACs in their association with ARL are discussed in the following subsections: ACs' independence, gender, financial expertise, meetings and size.

Table I: The relationship between AC' characteristics and ARL in the pertinent literature

\begin{tabular}{|c|c|c|c|c|}
\hline \multicolumn{5}{|c|}{ Panel A: The relationship of audit committees' attributes and ARL in countries other than UK } \\
\hline Authors & Setting/Sample & Aim & $\begin{array}{c}\text { The examined attributes } \\
\text { of } \mathrm{AC} \text { 跑 }\end{array}$ & Results \\
\hline Abdullah, (2007) & Malayyia & $\begin{array}{l}\text { It aims at identifying the relationship } \\
\text { between the composition of the boards } \\
\text { of directors and its audit committee and } \\
\text { the tendency of the release of audit } \\
\text { report on time. }\end{array}$ & - AC's Independence. & $\begin{array}{l}\text { A non-significance relationship } \\
\text { between the ratio of independent } \\
\text { director within the audit committee } \\
\text { and the timeliness of audit report. }\end{array}$ \\
\hline $\begin{array}{l}\text { Mohamad-Nor et al. } \\
(2010)\end{array}$ & Malaysia & $\begin{array}{l}\text { It aims at examining the impact of the } \\
\text { attributes of both the board of directors } \\
\text { and audit committees in Malaysian } \\
\text { listed companies on ARL. }\end{array}$ & $\begin{array}{l}\text { - Size } \\
\text { - Activity(meetingfreanencs). } \\
\text { - Independence } \\
\text { - Financial expertise. }\end{array}$ & $\begin{array}{l}\text { Although positive relationships are } \\
\text { found for the impact of audit } \\
\text { committees' size and activity on ARL, } \\
\text { non-significance association are } \\
\text { reported for audit committee's } \\
\text { independence and expertise and ARL. }\end{array}$ \\
\hline Abernathyet al (2014) & $\begin{array}{l}\text { USA, companies listed in } \\
\text { S\&P 500 for the years from } \\
2006 \text { to } 2008 .\end{array}$ & $\begin{array}{l}\text { It aims at examining the association } \\
\text { between accounting financial expertise } \\
\text { of audit committee's member and } \\
\text { financial reporting timeliness, measured } \\
\text { by ARL amoug other measures. }\end{array}$ & $\begin{array}{l}\text { Accounting financial expertise } \\
\text { of ac's members. }\end{array}$ & $\begin{array}{l}\text { The findings include a negative } \\
\text { relationship between the ratio of } \\
\text { public accounting experts as audit } \\
\text { committees' members and ARL. A } \\
\text { negative association also is found } \\
\text { between the accounting expertise of } \\
\text { audit committee' chair and ARL. }\end{array}$ \\
\hline Sultana et al. (2015) & $\begin{array}{l}\text { Australia, } 494 \text { companies } \\
\text { listed on ASX from } 2004 \text { to } \\
2008 \text {. }\end{array}$ & $\begin{array}{l}\text { The main objectire is to figure the out } \\
\text { the association between different } \\
\text { attributes of AC and the tendency of } \\
\text { ARL }\end{array}$ & $\begin{array}{l}\text { The financial expertise. } \\
\text { - The accumulated experience } \\
\text { - gender dirersity. } \\
\text { - Size. } \\
\text { - Independence. } \\
\text { - Diligence. }\end{array}$ & $\begin{array}{l}\text { Although a negative significant } \\
\text { association is reported between AC' } \\
\text { financial, accumulated expertise, and } \\
\text { AC's independence and ARL; non- } \\
\text { significance association is revealed } \\
\text { betwreen the gender, size and activity } \\
\text { of AC and ARL. }\end{array}$ \\
\hline Zalata et al., (2018) & $\begin{array}{l}\text { USA, listed US companies } \\
\text { from } 2007 \text { to } 2013 \text {. }\end{array}$ & $\begin{array}{l}\text { It aims at ascertaining the relationship } \\
\text { whether the gender of the financial } \\
\text { expertise of the AC's members matter } \\
\text { in relation to its impact on the earnings } \\
\text { management. }\end{array}$ & $\begin{array}{l}\text { - The financial expertise of } \mathrm{AC}^{\prime} \text { 's } \\
\text { members. } \\
\text { - Gender } \\
\text { - The combined effect of both } \\
\text { finsncial expertise and gender. }\end{array}$ & $\begin{array}{l}\text { Both the financial expertise and the } \\
\text { gender of the AC's members mitigate } \\
\text { the degree of earning management in } \\
\text { US companies. Besides, a negative } \\
\text { association is reported for the ratio of } \\
\text { female financial experts and earnings } \\
\text { management while non-significant } \\
\text { effect is found for male financial } \\
\text { experts. }\end{array}$ \\
\hline
\end{tabular}




\begin{tabular}{|c|c|c|c|c|}
\hline Bastwah et al, (2019) & $\begin{array}{l}\text { Malausia_listed } \\
\text { Malaysian companies } \\
\text { from } 2005 \text { to } 2011 .\end{array}$ & $\begin{array}{l}\text { The main objective of this study is } \\
\text { to identify the relationship } \\
\text { between the accounting expertise } \\
\text { of audit committee's chair and } \\
\text { ARL. }\end{array}$ & $\begin{array}{l}\text {-AC' chair: } \\
\text { - Accounting expertise. } \\
\text { - Equity shareholding. } \\
\text { - Tenure. } \\
\text { - Interlocking directorship. }\end{array}$ & $\begin{array}{l}\text { The accounting expertise of AC } \\
\text { chair' s is a significant determinant } \\
\text { to the audit report timeliness. } \\
\text { Besides, equity shareholding of the } \\
\text { AC 'chair posit the relationship } \\
\text { between their accounting expertise } \\
\text { and ARL while their tenure and } \\
\text { interlocking directorships are } \\
\text { insignificant in this regard. }\end{array}$ \\
\hline Qussiij and Taktak, (2018) & $\begin{array}{l}\text { Tunisia.Tunisian } \\
\text { listed companies for } \\
\text { the period of 2011- } \\
2013\end{array}$ & $\begin{array}{l}\text { The main objective is to assess the } \\
\text { relationship between the AC's } \\
\text { effectiveness and financial } \\
\text { reporting timeliness. }\end{array}$ & $\begin{array}{l}\text { - Independence. } \\
\text { - Financial expertise. } \\
\text { - Size. } \\
\text { - Activity. } \\
\text {-Authority. }\end{array}$ & $\begin{array}{l}\text { The findings showed a negative } \\
\text { relationship between the AC's } \\
\text { financial expertise and ARL, while } \\
\text { non-significant association is found } \\
\text { for all other attributes of } A C \text {. }\end{array}$ \\
\hline Mathuxa et al., (2019) & $\begin{array}{c}\text { Kenya, listed Kenyan } \\
\text { Companies over the } \\
\text { period } 2007-2016 \\
\text { yielding } 543 \text { firm-year } \\
\text { obserrations. }\end{array}$ & $\begin{array}{l}\text { The objective of the paper is to } \\
\text { find out the impact of corporate } \\
\text { governance mechanisms, including } \\
\text { the attributes of AC, on the } \\
\text { likelihood of companies to issue } \\
\text { their financial statements and get } \\
\text { their audit report on time. }\end{array}$ & - Expertise. & $\begin{array}{l}\text { Among other findings, the } \mathrm{AC}_{\mathrm{S}} \\
\text { expertise is positively related to } \\
\text { ARL. }\end{array}$ \\
\hline \multicolumn{5}{|c|}{ Panel B: The relationship of audit committees' attributes and ARL in UK } \\
\hline Ghafran, and Sofia (2018) & $\begin{array}{l}\text { UK, FTSE } 350 \\
\text { companies between } \\
2007 \text { and } 2010 .\end{array}$ & $\begin{array}{l}\text { It aims to identify the association } \\
\text { between the different types of } \\
\text { expertise hold by } A C^{\prime} \text { chair and } \\
\text { ARL. }\end{array}$ & $\begin{array}{l}\text { Financial, experiential and } \\
\text { monitoring experience of } \\
\text { AC's chair. }\end{array}$ & $\begin{array}{l}\text { The findings reveal that the } \\
\text { accumulated experience of AC's } \\
\text { chair over time along with their } \\
\text { monitoring expertise enhance the } \\
\text { timeliness of the financial reporting. } \\
\text { Besides, the findings indicate that the } \\
\text { adherence with the regulation } \\
\text { requirements of the AC's chair } \\
\text { mitigate any unfarorable lag in } \\
\text { financial reporting. }\end{array}$ \\
\hline
\end{tabular}

\subsection{ACS' INDEPENDENCE AND ARL}

ACs' independence is commonly evaluated by the percentage of the independent non-executive members, that is the higher the percentage the higher the indication of its independence (Habbash et al., 2013). In a meta-analysis of 27 studies (Pomeroy and Thornton, 2008) recognize the ACs' independence as an important clue of for the ACs' effectiveness in conducting their monitoring role over financial reporting. In addition, previous studies provide evidence on the potential advantage of AC's independence. For instance, the findings of (Bédard et al., 2004) suggest that having more independent directors in ACs improve their abilities to undertake their financial oversight responsibilities, especially in dealings with auditors and handling dispute resolution, which can be reflected in reducing ARL. This direction of thinking is consistent with the agency theory that perceive that independent director as having a crucial role in monitoring management actions and mitigating agency problems (Jensen and Meckling, 1976; Fama and Jensen, 1983; Kapoor and Goel, 2019), and in the case of the tension between shareholders and managers, independent directors are proven to act objectively and disregard considerations of self-interest (Fama and Jensen, 1983).

Abbott et al. (200o) report a negative relationship between ACs' independent and the likelihood of the financial misstatement and argue that independent ACs' 
members are more expected to have incentives toward effective monitoring which induce them to meet more frequently and to devote much time to handle the companies' issues. In addition, based on Australian dataset, (Sultana et al., 2015) provide empirical evidence that the independent ACs' members are significantly associated with shorter time period for the auditors to release their audit reports. Also; Raimo et al. (202I) argue that the highly independent ACs is oriented toward enhancing the quality and way of representations of the integrated reporting. Therefore, we can predict the direction of the relationship between AC's independence and ARL as follows:

$\mathrm{H}_{\mathrm{r}}$ : There is a negative association between ACs' independence and ARL.

\subsubsection{ACs' GENDER AND ARL}

Previous studies offer mixed findings about the implications of the effect of the ACs' female membership on the audit report timeliness. A strand of studies acknowledges the role of female directors in enhancing the monitoring role of AC, and in turn in lessening the ARL. For instance, Adam and Ferreira (2009) mention that as demonstrated by the regulatory bodies' legislations, the presence of female directors within the board add value to the companies' governance structure. In addition, Adam and Ferreira (2009) also argue that since female directors are not permeating to the notion of 'old boys', they are acting in similar manner like nonexecutive directors, thus they are expected to conduct better monitoring and oversight.

In similar vein, Velte (2018) argue that the effective AC would induce the external auditors to enrich the informational content of auditor's report by the inclusion of Key Audit Matters (KAMs) and report a positive relationship between female directors' percentage within the UK companies' AC and the readability of KAM in the auditor's report. Accordingly, the inclusion of woman directors posits AC's governance role and leads to better communication with the external auditors. Besides; Zalata et al. (2018) argue that the gender diversity matters in positing the AC's effectiveness and suggest that the effectiveness of AC's financial experts in mitigating the earning management practises are augmented in the case of female than male experts. More specifically, Zalata et al. (2018) provide the empirical evidence that explained that the contradiction in the literature around the effectiveness of the financial experts within AC and argue such contradiction is 
emanated from the gender heterogeny of the expert members with more superiority of female than male expert members. Also; Mangala and Isha (2019) provide an empirical example based on BSE 500 index companies that the appointment of female directors on the boards enhance the earning quality and the corporate reporting through constraining earning management practises and this result is justified by women's general orientation toward ethical behaviours and their nature as risk averse compared to men.

Another strand of studies reports a non-significance effect of gender diversity in enhancing the ACs' monitoring role and its effect in maintaining timely audit report. Subject to Sultana et al. (2015), the proponents of the agency theory argue that AC's effectiveness is a function of the degree of coherence in its members' attitudes and perceptions. Accordingly, since the literature repeatedly indicates the attitudinal differences between female and male directors toward the same business concepts, it is expected that gender diversity within small groups such as ACs would impair its coherence in the manner that deter its effectiveness as a governance mechanism (Sultana et al., 20I5). In addition, it is also expected to deteriorate ACs' synergy in the manner that create a tension between minority and majority subgroups, and in turn impair the AC's effectiveness (Sultana et al., 20I5). Sun et al. (20II) reports the non-significance association between gender diversity AC's effectiveness in mitigating earning management, suggesting the minor or null role of female directors.

Since the UKCG code is more oriented toward maintaining a diversity in boards' members in terms of gender and other demographic issues, and since it did not stipulate certain percentage of female directors within the boards and their committees, we state the hypothesis regarding the relationship between AC's gender diversity and ARL as follows:

$\mathrm{H}_{2}$ : There is a positive association between ACs' gender diversity and ARL.

\subsubsection{ACs' FinanCIAL EXPERTISE AND ARL}

Financial expertise is an important determinant of AC effectiveness that was under scrutiny by both academics and regulatory bodies (e.g.; Abbott et al., 2004; Krishnan and Visvanathan, 2008). Mangena and Pike (2005) suggest that ACs' expertise enhances financial disclosure, while its expert ability fosters earnings quality. Such expertise is particularly important to face the progressively complex 
information (Abbott et al., 2004; Beasley et al., 20Io), assure the quality of financial reporting (Chen et al., 2006), monitor sustainability reporting (Al-Shaer and Zaman, 2018), and improve the credibility and the quality of disclosed information (Smith Guidance, 2003). Hence, greater expertise of AC enhances its effectiveness and, consequently, the quality of the external audit, Ghafran and O'Sullivan (2017).

From the agency theory's perspective, the financial expertise of audit committees enhances the effectiveness of audit committees in conducting their role and also add value the audit quality in a manner that may support the readability of the audit report (Velte, 2020). For instance, Powell and Anisc (1997) contend that having ACs with financial expertise may help in reducing agency costs, as AC members are acquainted with the auditing and/or financial reporting process. They are capable of judgments and resolve any conflicts that may arise in the course of the audit. Similarly; Sultana et al. (2015) argue that the independent AC members who possess financial expertise and have past experience in ACs contribute to shorter ARL. In similar vein, Ghafran and Yasmin (2017) declare that AC chairs who have experience and monitoring expertise can help to reduce ARL. Additionally, Oussii and Taktak (2018) found a negative association between AC's financial expertise and ARL. Furthermore, Ghafran and Yasmin, (2018) highlight the protuberant role of AC's chair in enhancing its effectiveness in discharging its responsibilities. They investigate the relationship between the accumulated and monitoring experience of AC's chair and ARL suggesting a negative association between the expertise of AC's chair and ARL (Ghafran and Yasmin, 20I8). Accordingly, the third hypothesis is formulated as follows:

$\mathrm{H}_{3}$ : There is a negative association between ACs' financial expertise and ARL.

\subsubsection{ACs' DILIGENCE AND ARL}

Another stream of literature suggests a positive association between ACs' diligence, measured by frequency of meetings, and ARL (DeZoort et al., 2002). For instance, Nehme et al. (2015) contend that firms that have a large number of AC members, with financial experience, who meet more frequently are likely to have a longer ARL. The frequent meetings of ACs could be a sign of ineffectiveness, chiefly when the emphasis of meetings is on financial and control weaknesses. While frequent meetings could be interpreted as more committee 
diligence, which may result in lower audit fees, they may indicate more serious audit-related issues that would increase client risk, audit fees, and ARL. According to DeZoort et al. (2002), in a synthesis of the empirical audit committee literature, diligence (frequency of committee meeting) is an important determinant of audit committee effectiveness. Mohamad-Nor et al. (20I0) find that active AC shortens audit delay in Malaysia. Similarly; Syofyan et al., (202I) suggest that the number of ACs' meeting plays an important role in enhancing their oversight function to the level that ensure the timely release of auditors' report.

According to Chalu (202I), the agency theory recognizes the ACs' frequency of meeting as an indication of their robust monitoring. Based on this premise, it is argued that the higher the number of the meeting; the more chance of ACs to effectively monitor the audit process in the manner that might reduce ARL. In addition, As mentioned earlier, the Smith Guidance identifies that three meeting per year is prescribed as the minimum number of meetings that indicate the ACs' diligence in settling their role (Smith Report, 2003).

Accordingly, we expect the association between ACs' meeting frequency and ARL as follows:

$\mathrm{H}_{4}$ : There is a negative association between ACs' diligence and ARL.

\subsubsection{ACs' SIZE AND ARL}

As a part of their oversight role, ACs' members are responsible for detecting and settling any potential problems that may affect the goodness of the financial reporting process and to communicate with auditors in this regard (Chalu, 202I). The results of previous studies regarding the relationship between ACs' and ARL are inconclusive and contradicted. For instance, Mohamad-Nor et al. (2oro) find that larger audit committee shortens audit delay in Malaysia. However; Sultana et al. (2015) find no significance association between AC's size and ARL in Australia. Similarly, Oussii and Taktak, (2018) found no significant association between AC's size and ARL in Tunisia. In a meta-analysis study, Habib et al. (2019) reveal that four of the eight studies that examined this relationship reported a negative association between ACs' size and ARL, while the rest four studies reveal nonsignificant association. In contrary, the proponents of agency theory contend that increasing the size of ACs increase the likelihood of opportunistic behaviour, complicate the decision-making process, and give a chance for conflicts and 
disagreements to emerge, which hinders the auditing process (Jensen and Tang, 1993). Thus, large size of ACs may hinder active participation by members, which may decrease their ability to discharge their monitoring and control responsibilities. This notion of thinking is supported by empirical results of Nehme et al. (2015) who argue that the presence of a large number of board members with financial experience can be a source of conflicts with auditors, which may lead to a longer ARL. Similarly, Raweh et al., (202I) and Chalu (202I) report a positive association between AC's size and ARL. Our study also expects that bigger size ACs may dilute the oversight' role of their members and increase the miscoordination and tension between them, in the manner may deter the quality of the financial reporting and lead to longer delays in audit reports. Thus, our fifth hypothesis is formulated as follows:

$\mathrm{H}_{5}$ : There is a positive association between ACs' size and ARL.

\section{RESEARCH DESIGN}

\section{I SAmple AND Data}

Our sample includes non-financial companies listed in UK FTSE 350 over the periods from 2017 to 2019 and consists of 633 firm-year observations for $2 \mathrm{II}$ companies. Ghafran and O'Sullivan(2017) refers to the UK CG code's distinction between FTSE350 companies and other listed UK regarding the degree of compliance to the governance recommendations and mention that non-FTSE350 companies are relatively less adhering to such recommendation. Accordingly, we choose FTSE 350 companies since our aim is to examine the associations between AC's attributes as prescribed by the UK CG code and ARL.

The sample covers the period from 2017 to 2019; the last available three years while preparing this study subject to the data availability. The pandemic COVID-I9 significantly affected the financial reporting within UK for the period after $3 \mathrm{I}$ December 2019 (PWC, 2020), thus the fiscal year of 2020 is excluded from our data set. Data about the attributes of audit committees are manually collected from the profiles of audit committee's members published in their companies' integrated reports and available at the official sites of FTSE 350 companies. In addition, the remaining financial data are collected from Eikon Thomson Reuters database. 
Table 2: Description of the sample

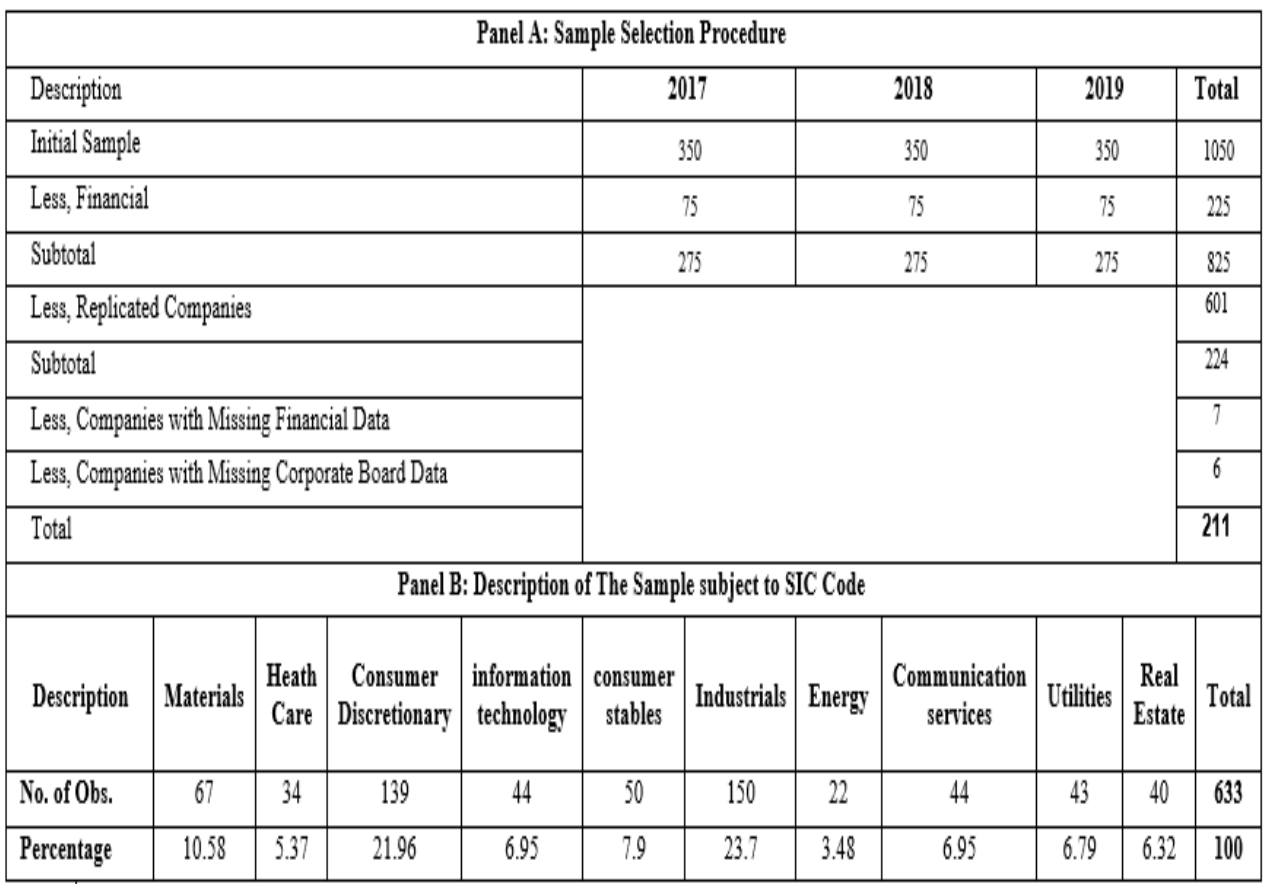

Panel A, Table 2, summarize the sample selection process. Due to the special auditing and governance requirements of financial companies (Ghafran and Yasmin, 20I8; Velte, 20I8, 2020), they are excluded from the target sample. In addition, the duplicated companies within FTSE350 index as well as the missing observations for the utilized variables are excluded. Accordingly, our sample include 2II companies over three years, from 2017 to 2019 , ending up with 633 firmyear observations covers the different industrial sectors within the UK. Panel B, Table 2, shows the sample distribution over industries, according to the Global Industry Classification Standard (GICS) .

\subsection{Variables Measurement}

Table 3 summarizes the measurement of the variables utilized in our study. The dependent variable is the audit report lag, ARL. The pertinent literature (e.g.; Bamber et al., 1993; Sultana et al., 2015; Baatwah et al., 2019; Al-Mulla and

${ }^{1}$ For further details about GICS, please refer to https://www.msci.com/gics\#: : text = GICS $\% 20$ sector $\% 20$ definitions \& text=Covering $\% 20$ Energy $\% 2 \mathrm{C} \% 20$ Materials $\% 2 \mathrm{C} \% 20$ Industr ials $\% 2$ C,Communication $\% 20$ Services $\% 20$ and $\% 20$ Utilities $\% 20$ Sector. 
Bradbury, 2020; Syofyan et al., 202I...etc) repeatedly employ the audit report lag as a proxy to the audit report timeliness, implying that the lower lag period between the financial statement date and the audit report date, the timelier the audit report. Similar to Salleh et al. (2017), ARL is computed as the number of days between the median of the audit report lag of a certain industrial sector and the audit report lag of each company within the same sector.

The independent variables are the attributes of the ACs. They could be summarized as follows. First, the AC's independence (ACIND) represents a dummy variable that is equal to one if all the AC's directors are independent nonexecutive directors, and zero otherwise. Second, the AC's female directors (ACFEM) denotes the percentage of female directors within the AC. Third, the AC's financial expertise (ACFEX) represents the percentage of AC's members hold financial expertise. We utilize the definition provided by (Velte, 2020) to identify the main criteria of audit committees' financial expertise. That is, the audit committee member is classified as holding a financial expertise if he/she currently or previously worked as CEO or CFO in other companies; and/or previously worked as CPA or worked in a big four auditing company; and/or hold $\mathrm{PhD}$ or work in academic position related to finance or accounting (Velte, 2020). The AC's meeting (ACMET) is our fourth independent variable as a proxy of AC's activity. It is computed as the log number of AC's meeting during the fiscal year. Finally, the size of $\mathrm{AC}$ (ACS) refers to the number of audit committee members.

Table 3: The Definitions of the Variables

\begin{tabular}{|c|c|c|}
\hline \multicolumn{3}{|c|}{ Dependent variable } \\
\hline ARL & $\begin{array}{l}\text { The difference between of the audit report lag' } \\
\text { median of a certain industrial sector and the } \\
\text { audit report lag of each company within the } \\
\text { same sector. }\end{array}$ & Salleh et al., (20I7). \\
\hline \multicolumn{3}{|c|}{ Independent Variables } \\
\hline ACIND & $\begin{array}{l}\text { A dummy variable that takes one if all AC's } \\
\text { members are independent non-executive } \\
\text { directors as announced in the annual report } \\
\text { and zero otherwise. }\end{array}$ & $\begin{array}{l}\text { Stewart \& Kent, 2006; Habbash et } \\
\text { al., (2013). }\end{array}$ \\
\hline ACFEM & The percentage of AC's female directors. & Sultana et al., (20I5); Velte, (20I8). \\
\hline ACFEX & $\begin{array}{l}\text { The percentage of AC's members possesses } \\
\text { financial expertise. }\end{array}$ & $\begin{array}{l}\text { Stewart \& Kent, (2006); Al-Shaer et } \\
\text { al., (2017); Al-Shaer \& Zaman, } \\
\text { (2018); Velte, (2020). }\end{array}$ \\
\hline
\end{tabular}




\begin{tabular}{|c|c|c|}
\hline ACMET & $\begin{array}{l}\text { The natural logarithm of the number of } \\
\text { the meetings held by the } \mathrm{AC} \text { per the fiscal year. }\end{array}$ & Soyemi et al., (2019). \\
\hline ACSIZ & The number of AC members. & $\begin{array}{l}\text { Stewart \& Kent,( 2006); Al- } \\
\text { Shaer \& Zaman, (2018). }\end{array}$ \\
\hline \multicolumn{3}{|c|}{ Control Variables } \\
\hline $\mathrm{ROA}$ & $\begin{array}{l}\text { The return on Assets as given by Thomson } \\
\text { Reuters Eikon. }\end{array}$ & $\begin{array}{l}\text { Habbash, (2OI2); Ghafran \& } \\
\text { O'Sullivan, (2OI7); Al-Shaer \& } \\
\text { Zaman, (2OI8). }\end{array}$ \\
\hline FSIZ & $\begin{array}{l}\text { The natural logarithm of total assets of a firm at } \\
\text { the end of the year. }\end{array}$ & $\begin{array}{l}\text { Mohamad-Nor et al., } \\
\text { (2OIO); Ghafran \& O'Sullivan, (20I7); } \\
\text { Al-Shaer \& Zaman, (2OI8); Velte, } \\
\text { (2020). }\end{array}$ \\
\hline LEV & $\begin{array}{l}\text { The ratio of long-term debt to total assets at end } \\
\text { of the year. }\end{array}$ & Al-Shaer \& Zaman, 2018; Velte, 2020 \\
\hline SUBSID & The number of subsidiaries at end of the year. & Loughran \& Mcdonald, 2020. \\
\hline FYE & $\begin{array}{l}\text { A dummy variable that equals to one when the } \\
\text { companies' balance sheet date is within the } \\
\text { busy reporting period (i.e., between 3I March } \\
\text { and } 30 \text { June), and zero otherwise. }\end{array}$ & Al-Mulla \& Bradbury, 2020. \\
\hline AUDTEN & $\begin{array}{l}\text { The length of the engagement period for the } \\
\text { exiting auditor, as reported by Thomson } \\
\text { Reuters Eikon. }\end{array}$ & $\begin{array}{l}\text { Abernathy et al., (20I4); Abdillah et } \\
\text { al., (20I9). }\end{array}$ \\
\hline AUDFEE & The natural logarithm of audit fees per year. & $\begin{array}{l}\text { Abernathy et } \\
\text { al., (20I4); Bhuiyan \& D'Costa, } \\
(2020) \text {. }\end{array}$ \\
\hline BODIND & $\begin{array}{l}\text { The percentage of independent directors } \\
\text { within the board. }\end{array}$ & Al-Mulla \& Bradbury, (2020). \\
\hline BODFEM & $\begin{array}{l}\text { The percentage of female directors within the } \\
\text { board }\end{array}$ & Elmagrhi et al., (20I7). \\
\hline BODSIZ & The number of directors in the board. & $\begin{array}{l}\text { Al-Shaer \& Zaman, (2018); Zalata et } \\
\text { al. (2018). }\end{array}$ \\
\hline BODMET & $\begin{array}{l}\text { The natural logarithm of the number of } \\
\text { the board meetings per year }\end{array}$ & Al-Shaer \& Zaman, (2018). \\
\hline BODFEX & $\begin{array}{l}\text { The percentage of directors hold financial } \\
\text { expertise within the board. }\end{array}$ & Velte, (2019). \\
\hline
\end{tabular}

We employ three sets of control variables to avoid any biased results. The first set is firm specific variables which includes the companies' financial performance; size; financial risk; complexity and reporting period. Similar to Ghafran and O'Sullivan, (2017), we included (ROA) that represents return on asset at year end, as the measure of companies' financial performance. It gives an indication to the degree of management' efficiency in utilizing its resources on behalf of shareholders (Habbash, 2012). Companies incurred losses may be reluctant to stimulate their audit firms to issue the audit report, while high profit companies 
are more enthusiastic to shorten the lag period of the audit period to accelerate the spread of good financial performance to the public (Afify, 2009).

Additionally, to control for variations in companies' size, FSIZ, is computed as the $\log$ of total assets at the yearend (Ghafran and O'Sullivan 2017 and Velte, 202O). It is argued that large size companies are financially capable to pay higher audit fees to ensure the acceleration of the issuance of the audit report as soon as possible (Afify, 2009). Further, since large size companies are subject to strong external monitoring from different regulatory bodies, management may purse to minimize the audit report lag as a response to this robust monitoring (Afify, 2009; Mohamad-Nor et al., 20Io). Hence, a negative association is expected between SIZE and the ARL.

The companies' financial risk (LEV) represents the ratio of long-term debt to total assets at yearend (Al-Shaer and Zaman, 20I8). It is argued that auditors may consume greater due consideration for companies with higher financial risk in the manner that may lead to longer ARL (Sultana et al., 2015). Since the audit firms may augment their disclosure of KAMs for highly leverage companies (Velte, 2020); it is expected that audit companies may consume longer time to finish the audit process and release the report. Thus, we expect a positive relationship between LEV and ARL. In addition, (SUBSID) denotes to the number of subsidiaries, which is used to control for the degree of a firm's complexity (Loughran and Mcdonald, 2020). According to Durand (2019), the more the number of subsidiaries; the longer the ARL, thus; we expect a negative relationship between the SUBSID and ARL. Finally, similar to Al-Mulla and Bradbury (2020), FYE is utilized as a dummy variable that equals to one when the companies' balance sheet date is between 3 I March and 30 June (the busy reporting period) and zero otherwise.

The second set of control variables is related to the audit firm. Similar to Abernathy et al., (20I4), we add some auditor related variables such as the tenure period of the exiting auditor (AUDTEN) and the auditors' fees (FEES). Similar to Abdillah et al. (2019), (AUDTEN) represent the length of the exiting auditors' tenure in years. In addition, in line with Abernathy et al. (20I4), (FEES) is calculated as the log on the audit fees paid at year end. It is argued that the financial expertise held by AC members is accompanied with higher audit fees and shorter 
auditors' tenure (Abernathy et al., 2014). Accordingly, both FEES and TENURE are expected to have negative relationship with ARL.

Similar to Sultana et al. (2015) and Al-Shaer and Zaman (2018), our third set of control variables is added to control for variations in the corporate board's attributes as follows. First, BODIND is defined as the percentage of independent directors to the total number of board's directors. Bhuiyan and D'Costa, (2020) report a negative and positive association between ARL and BODIND, thus we also expect a negative relationship in this regard. Second, BODFEM represents the percentage of female members on the board. Third, BODS is utilized as the total number of directors in the directors' board. Lipton and Lorsch (1992) argued that extending the number of the board of directors beyond eight or nine may overwhelm their engagement of boards' activities. Accordingly, similar to the reported results of Sultana et al. (2015), we expect a negative association between board size and ARLs. In other words, the smaller the board size, the longer the ARL. Fourth, BODMEET is the number of board meetings during the fiscal year. Fifth, BODFEX is the percentage of board members with financial expertise.

\subsection{MODEl SPECification}

In order to identify the appropriate model that specifies our panel data, we follow the procedural approach provided by (Dougherty, 20II) as follows. First, we utilized Durbin-Wu-Hausman (DWH) specification test to examine the existence of random effect in comparison to the fixed effect. As shown in Table 4, the results of DWH test indicate that, at the significance levels of $1 \% ; 5 \%$ and Io\%, we failed to reject the null hypothesis that the random effect is the appropriate model, where the p-value is 0.1665 . Accordingly, the random rather than the fixed effect regression model need to be utilized. Second, as stated by Dougherty (20II), since the DWH test do not indicate significant differences in the effects, it is important to conduct the Breusch and Pagan Lagrangian multiplier(LM) test for random effects to determine whether there are differences in error variance across companies. The results presented in Table 4 indicate that there is no significant difference across entities since the p-value of 0.8999 is greater than the significance thresholds, implying that the precedence of OLS model over random effect model.

As a double check, we also employee the F-test to compare between the fixed effect model and OLS model. The F-test identifies the extent to which the fixed effect 
model could enhance the models' goodness-of-fit (Park, 2oII). Table 4 reports insignificant $\mathrm{P}$-value of F-test at the different significant levels where the p-value $=0.9159$. this result indicate that we fail to reject the null hypothesis that all the slope coefficients are zero and conclude that OLS is much preferable for our data set rather than fixed effect model.

Table 4: Tests for model specification

\begin{tabular}{|c|c|c|c|}
\hline Test/Model & $\begin{array}{c}\text { Durbin-Wu-Hausman } \\
(\mathrm{DWH}) \text { test }\end{array}$ & $\begin{array}{c}\text { Breusch and } \\
\text { Pagan Lagrangian multiplier } \\
\text { test for random effects }\end{array}$ & F-Test \\
\hline & Prob $>$ chi $2=0.1826$ & Prob $>$ chibar $2=0.8999$ & Prob $>\mathrm{F}=0.9507$ \\
\hline${ }^{* * *} \mathrm{p}<$. oI $,{ }^{* *} \mathrm{p}<.05,{ }^{*} \mathrm{p}<. \mathrm{I}$ & & \\
\hline
\end{tabular}

In order to ensure the validity of OLS assumptions, we employee the ShapiroWilks test to examine the normal distribution of residuals. In untabulated results, since Prob $>z=0.219$ I is greater than the significance thresholds of 0.I;0.05 and o.I, we fail to reject the null hypotheses and conclude that the residuals are normally distributed. In addition, as suggested by Dougherty (20II), and similar to Habbash et al., (2013); Al-Ebel et al., (2020) and Raweh et al., (202I), we utilize OLS regression with robust standard errors to handle any potential effect of heteroscedasticity and autocorrelation. Accordingly, since the aim of our paper is to examine the effect of the AC's attributes as prescribed by the UK CG code on the audit report timeliness, the following regression is estimated as follow:

$$
\begin{aligned}
& \text { ARLit }_{i t} \beta_{0}+\beta_{1} \text { ACIND }_{i t}+\beta_{2} \text { ACFEM }_{i t}+\beta_{3} \text { ACFEX }_{i t}+\beta_{4} \text { ACMET }_{i t}+\beta_{5} \text { ACSI } \\
& Z_{i t}+\beta_{6} \text { ROA }_{i t}+\beta_{7} \text { FSIZ }_{i t}+\beta_{8} \text { LEV }_{i t}+\beta_{9} \text { SUBSID }_{i t}+\beta_{10} \text { FYEX }_{i t}+\beta_{11} \text { AUDTEN }_{i t} \\
& +\beta_{12} \text { AUDFEE }_{i t}+\beta_{13} \text { BODIND }_{i t}+\beta_{14} \text { BODFEM }_{i t}+\beta_{15} \text { BODSIZ }_{i t}+\beta_{16} \text { BO } \\
& \text { DMET }_{i t}+\beta_{17} \text { BODFEX }_{i t}+\text { INDUST }_{\text {YEAR }}+\varepsilon_{i t}
\end{aligned}
$$

where $i$ and $t$ denote the firm and year indexes respectively, ARL is the audit report lag; ACIND represent the audit committees' independence; ACFEM is the percentage of female directors on the audit committee; ACFEX is the percentage of directors with financial expertise on the audit committee; ACMET in the number of audit committee' meetings; ACSIZ is the audit committee's size; ROA denotes the firm's profitability; FSIZ is the natural logarithm of total assets; LEV is a proxy for financial risk; SUBSID is as a proxy of the degree of complexity, measured as the company's number of subsidiaries; FYE is a proxy of the auditors' reporting timing; AUDTEN represents the number of years in the engagement 
period for the exiting auditor; AUDFEE is the natural logarithm of audit fees; BODIND represents the board independence; BODFEM represents the percentage of female members on the board; BODSIZ represents the board size; BODMET in the number of board's meetings; BODFEX is the percentage of board members with financial expertise; INDUST and YEAR denotes the industry and years fixed effect respectively; $\varepsilon$ is the error term.

\section{4-RESULTS}

\section{4-I DESCRIPTIVE ANALYSIS AND CORRELATION ANALYSIS}

Table 5 shows the descriptive statistics for the utilized variables. Similar to Al-Ebel et al. (2020) and Ghaleb et al. (202I), all continuous variables that have extreme values were winsorized at $\mathrm{I} \%$ to eliminate the effect of extreme values. Panel $\mathrm{A}$ of Table 5 shows the descriptive statistics for the continuous variables. The mean value of ARL adjusted for the different industrial sectors in the $U K$ is approximately 6I days, with a median value of 59 days. With respect to the AC's attributes, the results show that the average mean of ACFEM is 3I percent. Our result is slightly greater than this reported by (Velte, 20I8) who reports an average mean of AC's female directors of 24 percent, suggesting the UK companies' tendency toward increasing the female representation on AC. ACFE is about 58 percent, indicating that more than half of AC's members of FTSE 350 companies hold financial expertise. On average, ACS is around four members and the mean $\log$ of ACMEET is four times per year.

With respect to control values, Panel A of Table 5 shows also that the average ROA, SIZE and LEV of the FTSE 350 companies is 0.06 , II and 0.4 correspondingly. These figures are consistent with (Velte, 2020)'s results in which the reported ROA, SIZE and LEV are 0.05, 13 and 0.5 respectively. The standard deviation of SUBSID is I29 which implies a high dispersion in the degree of the complexity among FTSE 350 companies. The results also show that, the mean number of years of existing auditors (AUDTEN) is four years and the average log audit fees paid (FEES) is 6.23 percent.

The descriptive statistics as shown in Panel A, Table 5 also demonstrate some characterises of corporate board diversity within FTSE 350 companies. About 72 percent of the board members are considered as independent directors (BOIND). Additionally, nearly the quarter of boards' directors of FTSE 350 companies is 
female (BODFEM). Besides, the average number of board members (BODS) is nine and the mean log number of their meeting per year (BODMEET) is approximately 0.30. Finally, more than half of FTSE 350 companies' board members possess financial experience (BODFE).

Table 5, panel B shows the descriptive statistics for dummy variables, ACIND and FYE. The results indicate that roughly 96 percent of ACs in FTSE 350 companies are fully independent (ACIND). This result indicates the assertion mentioned earlier that FTSE 350 companies cpmply the UK CG code in much rigorous way. In addition, more than three quarters of FTSE 350 companies are issuing their financial reporting within the busy reporting period that is between 3I March and 30 June, while the rest quarter report in the non-busy period (FYE).

Table s: Summary statistics

\begin{tabular}{|c|c|c|c|c|c|c|}
\hline \multicolumn{7}{|c|}{ Panel A: Summary Statistics for Continuous Variables } \\
\hline & Obs & Mean & SD & Median & p25 & p75 \\
\hline ARL & 633 & 6I.II & 16.07 & 59 & 52 & 67 \\
\hline ACFEM & 633 & 30.63 & 8.13 & 33.33 & 20 & 40 \\
\hline ACFEX & 633 & 57.97 & 14.29 & 60 & 40 & 75 \\
\hline ACMET & 633 & 4.36 & 0.48 & 4 & 4 & 5 \\
\hline ACSIZ & 633 & $4 . \mathrm{II}$ & 0.79 & 4 & 3 & 5 \\
\hline ROA & 633 & 0.06 & 0.03 & 0.06 & 0.02 & o.IO \\
\hline FSIZ & 633 & 10.58 & 0.35 & 9.32 & 8.98 & 9.82 \\
\hline LEV & 633 & 0.42 & 0.09 & 0.23 & O.II & 0.33 \\
\hline SUBSID & 633 & I28.84 & 85.79 & 97 & 38 & 247 \\
\hline AUDTEN & 633 & 3.74 & I.7O & 3 & 2 & 6 \\
\hline AUDFEE & 633 & 6.23 & 0.32 & 6.23 & 5.85 & 6.62 \\
\hline BODIND & 633 & $7 \mathrm{I} .84$ & 12.36 & 72.73 & 64.29 & 80 \\
\hline BODFEM & 633 & 25.01 & 6.6I & 25 & 16.67 & 33.33 \\
\hline BODSIZ & 633 & 8.64 & 1.25 & 9 & 7 & IO \\
\hline BODMET & 633 & 0.30 & 0.09 & 0.30 & 0.26 & 0.33 \\
\hline BODFEX & 633 & 56.18 & 8.76 & 55.56 & 45.45 & 66.67 \\
\hline \multicolumn{7}{|c|}{ Panel B: Summary Statistics for Dummy Variables } \\
\hline \multirow{3}{*}{ ACIND } & Obs & Value & Freq. & \multicolumn{3}{|c|}{ Percent } \\
\hline & \multirow{2}{*}{633} & $\mathrm{o}$ & 26 & \multicolumn{3}{|c|}{$4 . \mathrm{II}$} \\
\hline & & $\mathrm{I}$ & 607 & \multicolumn{3}{|c|}{95.89} \\
\hline \multirow{2}{*}{ FYE } & \multirow{2}{*}{633} & $\mathrm{o}$ & 150 & \multicolumn{3}{|c|}{23.7} \\
\hline & & I & 483 & \multicolumn{3}{|c|}{76.3} \\
\hline
\end{tabular}

Table 6 shows the Pearson correlation and multicollinearity statistics results. According to Bouazizet al. (2020), the correlation matrix is not demonstrating a multicollinearity issue in the case that the correlation between the 
independent variables is less than o.8. This suggest that there is no multicollinearity issue in our data as shown in Panel A, Table 6. Furthermore, the results shown in panel B, Table 6 indicate the lack of multicollinearity problem among the independent variables. That is as stated by Bager et al. (2017), the variance inflation factors (VIFs) for the independent variables should be less than Io and the tolerance levels should be more than 0.2 to conclude that there is no multicollinearity issue.

Table 6: Correlation matrix

\begin{tabular}{|c|c|c|c|c|c|c|c|c|c|c|c|c|c|c|c|c|c|c|}
\hline & \multicolumn{16}{|c|}{ Panel A: Pearson correlation for Continuous Variables } & \multicolumn{2}{|c|}{$\begin{array}{c}\text { Panel B: } \\
\text { Multicollinearity } \\
\text { statistics }\end{array}$} \\
\hline & ARL & ACFEM & ACFE & ACMET & Acsiz & ROA & FBII & LEV & SUBSID & AUDTEX & AUDFER & BODND & BODFEM & Bopsiz & BODMET & BODFEX & $\mathrm{VIP}$ & Tolerrace \\
\hline ARL & 1 & & & & & & & & & & & & & & & & & \\
\hline ACFEM & 0.0438 & 1 & & & & & & & & & & & & & & & 1.48 & 0.94 \\
\hline ACFEX & $0.0800^{*}$ & $0.0761^{\circ}$ & 1 & & & & & & & & & & & & & & 1.07 & 0.88 \\
\hline ACMET & $-0.0896^{*}$ & 0.0079 & $\cdot 0.0051$ & 1 & & & & & & & & & & & & & 1.07 & 0.94 \\
\hline ACSIZ & $\cdot 0.0634$ & 0.0436 & $-0.1848^{\circ}$ & $0.0743^{*}$ & 1 & & & & & & & & & & & & 1.14 & 0.88 \\
\hline ROA & 0.0382 & -0.0149 & -0.0058 & -0.0312 & $\cdot 0.0686$ & 1 & & & & & & & & & & & 1.98 & 0.51 \\
\hline SIZE & $\cdot 0.0141$ & 0.0003 & -0.0051 & -0.0434 & 0.0423 & $.2566^{*}$ & 1 & & & & & & & & & & 2.32 & 0.43 \\
\hline LEV & .0074* & 0.0495 & $-0.0860^{\circ}$ & $0.0775^{*}$ & $0.1344^{*}$ & $.0 .3406^{\circ}$ & $0.3060^{*}$ & 1 & & & & & & & & & 1.31 & 0.76 \\
\hline SUBSID & -0.026 & 0.0008 & $0.0920^{*}$ & 0.0029 & 0.0604 & $-0.0983^{*}$ & 0.5972 & $0.2042^{\circ}$ & 1 & & & & & & & & 1.65 & 0.61 \\
\hline AUDTEN & $\cdot 0.0278$ & -0.0334 & $0.0712^{*}$ & $-0.0715^{*}$ & $-0.1040^{\circ}$ & $-0.0774^{*}$ & -0.0218 & 0.0228 & $0.0875^{*}$ & 1 & & & & & & & 1.09 & 0.92 \\
\hline AUDFEE & $\cdot 0.0305$ & $0.1137^{\star}$ & $0.1322^{*}$ & $0.1933^{*}$ & $0.2122^{*}$ & -0.014 & 0.0616 & 0.0386 & 0.0314 & $\cdot 0.0219$ & 1 & & & & & & 1.16 & 0.86 \\
\hline BODIND & 0.0142 & $-0.0990^{\circ}$ & $0.0935^{\circ}$ & -0.002 & $\cdot 0.0115$ & $-0.1908^{\circ}$ & $0.2517^{\circ}$ & $0.1391^{\circ}$ & 0.143 & -0.0106 & 0.0066 & 1 & & & & & 1.22 & 0.82 \\
\hline BOOFEM & 0.0043 & $\cdot 0.0045$ & $-0.0777^{*}$ & 0.0248 & 0.0284 & 0.0574 & $0.1977^{*}$ & 0.063 & $0.1367^{\circ}$ & $0.1013^{*}$ & 0.0113 & $0.1320^{*}$ & 1 & & & & 1.1 & 0.91 \\
\hline BODS12 & $\cdot 0.0427$ & $\cdot 0.0087$ & $\cdot 0.0011$ & -0.0261 & 0.0243 & $-0.1680^{\circ}$ & $0.5842^{*}$ & $0.3113^{*}$ & $0.3743^{*}$ & $0.0777^{*}$ & 0.0107 & $0.2247^{*}$ & $0.1223^{*}$ & 1 & & & 1.1 & 0.91 \\
\hline BOOMET & $0.096 \theta^{*}$ & $\cdot 0.0014$ & $-0.0739^{\circ}$ & 0.0075 & 0.0669 & -0.012 & -0.0038 & $-0.0685^{\circ}$ & -0.0347 & 0.0097 & 0.0251 & $-0.0684^{*}$ & 0.0086 & -0.0384 & 1 & & 1.03 & 0.97 \\
\hline BODFEX & 0.0299 & 0.0159 & $-0.0737^{*}$ & -0.0427 & $\cdot 0.0385$ & $0.1473^{*}$ & $-0.1611^{*}$ & $-0.1318^{*}$ & $-0.0844^{*}$ & 0.0058 & $\cdot 0.0948$ & $-0.3018^{*}$ & -0.0629 & -0.1262 & 0.0569 & 1 & 1.81 & 0.62 \\
\hline & & & & & & & & & & & & & & & & & 1.34 & \\
\hline
\end{tabular}

\section{4-2 Multivariate Results}

Table 7 shows the results of the regression analysis. Overall, our model reveals the significant effect of the AC's attributes in explaining the variance in ARL (pvalue $<0.00$ ). The value of adjusted $R^{2}$ is 0.37 , suggesting that around $37 \%$ of the change in the audit report timeliness within the UK is imputed from the variations in AC's attributes, namely (independence; gender; financial expertise; diligence and size). To begin with, as presented in Table 7 , a significant and negative relationship was found between $A C I N D$ and a $A R L\left(\beta_{1}=-5.8 \mathrm{I}\right.$ with $\mathrm{p}$-value $=0.08$ ); thus, $\mathrm{H}_{\mathrm{I}}$ is accepted. This implies that the more the number of independent directors in ACs, the shorter the lag period for auditors to issue the audit report. Similarly, Wan-Hussin and Bamahros (2013) and Sultana et al. (2015) 
indicate that greater ACs' independence is accompanied with shorter audit delay. In addition, our result is consistent with the perception of agency theories about the prominent oversight role of the independent directors in refining the financial reporting process and in improve the timeliness of financial disclosure. Consistently, Raimo et al., 202I report a positive association between the ACs' independence and the quality of the integrated reporting.

Table 7: Regression Results

\begin{tabular}{|c|c|c|}
\hline Variables & \multicolumn{2}{|c|}{ Results } \\
\hline Independent Variables & Coef & $\mathrm{t}$ \\
\hline ACIND & $-5.8 \mathrm{I}$ & $-1.77^{*}(0.08)$ \\
\hline ACFEM & 0.05 & 0.68 \\
\hline ACFEX & 0.07 & I. 45 \\
\hline ACMET & -19.23 & $-1.64 *(0.10)$ \\
\hline ACSIZ & -0.05 & -0.06 \\
\hline \multicolumn{3}{|c|}{ Control Variables } \\
\hline $\mathrm{ROA}$ & -22.62 & -0.98 \\
\hline FSIZ & 0.74 & 0.28 \\
\hline LEV & -7.04 & -0.23 \\
\hline SUBSID & O.OI & 0.74 \\
\hline FYE & 3.12 & $2.2 \mathrm{I}^{* *}(0.03)$ \\
\hline AUDTEN & -0.36 & -0.87 \\
\hline AUDFEE & -3.82 & -1.89* (0.06) \\
\hline BODIND & 0.02 & -0.26 \\
\hline BODFEM & 0.17 & 1.59 \\
\hline BODSIZ & 0.26 & $0.4 \mathrm{I}$ \\
\hline BODMET & 18.23 & 0.97 \\
\hline BODFEX & -0.03 & -0.38 \\
\hline Constant & 25.59 & 0.94 \\
\hline Year and industry effect & \multicolumn{2}{|c|}{ Controlled } \\
\hline Number of Obs. & \multicolumn{2}{|c|}{633} \\
\hline P. Value & \multicolumn{2}{|c|}{0.000} \\
\hline R-Squared & \multicolumn{2}{|c|}{0.37} \\
\hline
\end{tabular}

Table 7 shows a non-significant and positive relationship between ACFEM and $\operatorname{ARL}\left(\beta_{2}=-0.05\right)$; thus, we reject $\mathrm{H}_{2}$. Similar results are also reported by Singh and Sultana (20II); Zaitul and Desi Ilona (2018) and Kayleen and Harindahyani (2019). 
The insignificant role of female directors in UK companies' ACs may be justified as follows. First, Sultana et al. (2015) argue, from the agency perspective, that the gender diversity within a small group may lead to losing the synergistic effectiveness of ACs since it leads to the formation of majority versus minority units. Since the UK regulations do not stipulate a fixed quota for ACs' gender diversity, UK companies may desire to involve female members in their ACs to avoid any criticism may be raised in the case of not satisfying the UK CG code's recommendations of gender diversity. Chen et al., (2016) indicate this notion of thinking by arguing that "female directors are not merely tokens" and that companies may be concerned with the female director's representation with the intent of merely lessening any criticism otherwise. Second, compared to the male directors, the conservative nature of female directors from one side (Schubert, 2006 and Oradi and Izadi, 2020); and their risk adverse attitude from the other side (Francis et al., 2015) may compel them to ask external auditors to conduct more reviewing activities that may be time consuming in the manner that expands the audit period and lead to longer ARL.

Contrary to our expectation, as reported in Table 7 , results reveal a non-significant and positive relationship between $A C F E X$ and $\operatorname{ARL}\left(\beta_{3}=0.07\right)$; thus, we reject $\mathrm{H}_{3}$. In consistent with our results, Salleh et al., (2017) also find non-significant association between AC's financial expertise (accounting experience) and ARL in Malaysia. Similarly, a number of previous studies could not find a significant association between the accounting expertise of AC's members and ARL (Mohamad-Nor et al., 20Io; Nelson and Shukeri, 20II); Knechel and Sharma (20I2); Wan-Hussin and Bamahros (2013). It is possible to justify this result as follows. First, some studies argue that AC' financial expertise improves the effectiveness of AC and reduces ARL only if the expertise is held by a member with hierarchical power, specifically, the chair of $\mathrm{AC}$ (Abernathy et al., 2014). This conclusion is in line with what DeFond et al. (2005) argue regarding the role of AC's chair with accounting expertise in improving the monitoring role of the committee. In addition, the accounting expertise of the chair may help him to effectively undertake responsibilities including overseeing the quality of financial reports, monitoring the internal and external auditors, and managing $\mathrm{AC}$ meetings (Beasley et al., 20Io; Tanyi and Smith, 20I5; Baatwah et al., 2019). Other studies argue that the measure of financial/accounting expertise determines the 
effectiveness of AC's expertise. AC's financial expertise can be classified, according to its sources, into (public accountant, $\mathrm{CFO}$ and both types of expertise). ARL is only reduced when the source of expertise is a public accountant (Baatwah et al., 2019). Second; Habib et al., (2019) criticize that the UK CG code does not clarify the notion of financial experience required by at least one member of UK companies' audit committees. Rather, the code generally refers to the importance of audit committee's members to acquire proficient skills and competences in the industry sector domain (Habib et al., 2019).

As expected, a significant and negative relationship is reported between ACMET and ARL ( $\beta_{4}=-19.23$ with $p$-value $\left.=0.10\right)$; thus, we accept $\mathrm{H}_{4}$. This implies that the more frequent of ACs, the shorter the ARL. This result is consistent with Mohamad-Nor et al. (2010) and Baatwah et al. (2019). In addition, this result is consistent also with the premise of agency theory that argue that the more frequent of ACs provide a greater room for the ACs' members to practise their oversight over the auditing process in the manner that could lessen the audit period and it turn the time to release the audit report (Chalu, 202I). In this regard, Habib et al. (2019) indicate that ACs that meets frequently are more capable to detect and handle any internal control weakness in the manner that could mitigate the auditors' queries and in turn lessen the auditors' working hour.

Based on the 22 interviews with ACs' members of three Canadian listed companies, Gendron and Bedard (2006) identify the financial reports accuracy, the financial discloser tone, the internal control effectiveness and the audit quality as the most important topics that are repeatedly discussed during ACs' meeting. Also, Felo and Solieri (2008) refer to the crucial role of ACs in maintaining quality in the companies' financial reporting. In addition, Fontaine et al. (2016) assert that ACs, formally and informally, communicate with the auditors and management, to mitigate any concerns relating to auditors' independence and to settles any disputes between both parties. Accordingly, the frequent ACs' meeting helps the auditors to effectively perform their work in the manner that would accelerate the release of the audit report.

Regarding the relationship between ACSIZ and ARL, Table 7 indicates a nonsignificant and negative association $\left(\beta_{5}=-0.05\right)$; thus, we reject $\mathrm{H}_{5}$. In the line of this result, Sultana et al. (2015); Oussii and Taktak, (2018) and Syofyan et al., (202I) report a non-significant effect of ACs size on the change of ARL. However, our 
result is not aligned with the premise of agency theory that larger ACs badly contribute the financial reporting quality and lead to longer time for auditors to release their reports. A possible justification in this regard could be stemmed from the thinking that the quality attributes of ACs' members in terms of their educational level and the type and tenure of their expertise may make a difference, rather than merely their number. In this regard, Felo and Solieri (2008) indicate that the ACs members with industry and financial expertise positively enhance the companies' disclosure quality, while those members who are independent and previously hold executive positions negatively affect the disclosure quality. Also; Raweh et al., (202I) assert the importance of ACs' qualitative attributes in such ACs' members with both industry and financial expertise are more effective in enhancing the timely financial reporting and audit quality.

We utilize three sets of control variables. Regarding the first set, the firm specific variables, we fail to find a significant relationship between ROA and ARL. In addition, incompatible with (Habib and Bhuiyan, 2oII) and (Singh and Sultana, 20II) who report a significant and negative relationship between SIZE and ARL, our results reveal a non-significant and positive relationship in this regard. Similar non-significant association is reported by (Raweh et al., 202I). A possible justification, based on the descriptive statistics in Panel B, table 5, is that the financial statements of more than three quarters of FTSE 350 companies are subject to audit within the busy season and about 97 percent these companies are audited by big four auditing firms (AIM Survey, 20I8), which makes it reasonable that external auditors consume longer time to finalize auditing activities. Besides; similar to Chan et al. (2016), our results report a negative but nonsignificant association between LEV and ARL, implying that companies with higher financial risks have shorter ARL. Moreover, the results reveal a positive but nonsignificant association between SUSID and ARL. Habib and Bhuiyan (20II) indicate that the larger the number the subsidiaries a company have, the longer the ARL. Finally, at significance level of $5 \%$, our results indicate a positive and significance association between FYE and ARL $\left(\beta_{10}=3.12\right.$, p-value=0.03). This implies that companies that subject to the auditing processes within the busy season tends to have longer ARL.

The second set of control variables is the audit firm related variables. We find a negative but nonsignificant relationship between AUDTEN and ARL. A non- 
significant association is also reported by (Al-Ebel et al., 2020) and (Raweh et al., 202I). Habib and Bhuiyan (2OII) indicate that the longer the auditor tenure, the shorter the lag period between the financial statement date and the auditors' report date. Also, the learning effect as the result of longer audit tenure (Velte, 2020), may shorten ARL. In addition, at significance threshold of $\mathrm{I} \%$, our results indicate a negative and significant relationship between FEES and ARL $\left(\beta_{12}=-0.05\right.$, $\mathrm{p}$-value $=0.06$ ). In this regard, Afify (2009) contend that the higher audit fees give the incentives of audit companies to shorten the ARL as possible.

Our third set of control variables contains the corporate board attributes. Similar to Chan et al. (2016), the findings reveal a non-significant relationship between BODIND and ARL. This result is not consistent with Afify (2009) who report a significant relationship in this regard arguing that independent directors can play a stronger monitoring role over management in the manner that could enhance the quality of financial reporting, enable more efficient and effective auditing, and therefore lessening the ARL. In addition, compatible with Chalu, (202I)'s work, our findings indicate a nonsignificant relationship between BODFEM and ARL Our results also report a positive but non-significance relationship between BODS and ARL. A possible justification of this result may be driven by the agency theory, as large board size may suffer from mis-coordination problems, harder communications, and slower decision-making (Merendino and Melville, 2019; Chouaibi et al., 202I) in a manner that may complicate the external auditors' work and lead to longer ARL. Similarly, consistent with Singh and Sultana (20II), the results reveal a nonsignificant association between BODMEET and ARL. Finally, a nonsignificant relationship is also reported between BODFE and ARL.

\section{5- ADDitional ANALYSiS}

\section{5-I The Number of Female Directors and ARL: The Critical Mass}

According to the critical mass theory, the number of female directors make a difference, that is the potential consequence of female directors' representation may not be achieved unless their number is reaching certain lower limit (Oradi and Izadi, 2020). Correspondingly, Liu et al. (2014) maintain that three or more female directors within the board may add stronger effect than fewer female directors' involvement. Based on this, we utilize the notion of the critical mass theory to 
study the impact of the number of female directors on ARL. We replace the measurement of the gender diversity from the percentage of female directors on ACs (ACFEM) with three dummy variables as follows. The first dummy variable; ONEFEM equals one if the AC has only one female director and zero otherwise. TWOFEM is the second dummy variable that takes the value of one in the case of the involvement of two female directors within the AC and zero otherwise. THREEFEM is the third dummy variable that equal one if the ACs have three or more female members and zero otherwise. We maintain other independent and control variables the same as the main analysis.

Panel A, Table 8 shows the summary statistics of the three added variables. Based on 633 firm-year observations, about 4I percent of ACs in FTSE 350 companies have one female directors, and nearly 35 percent have two female members. However, only 9 percent maintain three or more female directors within the ACs. Panel B, Table 8 shows the regression results. The reported results for the independent variables are all consistent with the results of the main analysis (Table 7). Regarding the added dummy variables, the results fail to find a significance association between either ONEFEM and ARL $\left(\beta_{2}=0.25\right)$ nor TWOFEM and $\operatorname{ARL}\left(\beta_{3}=0.25\right)$ at any significance levels of $1 \% ; 5 \%$ and $10 \%$. However, at significance level of $\mathrm{I} \%$, the results indicate a positive and significant association between THREEFEM and ARL ( $\beta_{4}=5.01$, $p$-value $=0.07$ ), implying that the more the female director's membership in the ACs, the longer the ARL.

Our results are consistent with Sellami and Cherif (2020) who conclude that the mere presence of female directors in ACs is not enough to enhance the audit quality as proxied by the higher audit fees. Rather, the professional expertise of the female directors is a key attribute that is accompanied by increasing the audit fees (Sellami and Cherif, 2020). That is because the highly experienced directors are more inclined to acquire extensive knowledge about their companies' internal operations and also are more motivated to protect the reputation of their business by demanding higher quality auditing and assurance services in the manner that might increase the audit efforts and in turn the audit fees. Accordingly, the quality, rather than the quantity of the female directors may add value to ACs' effectiveness (Sellami and Cherif, 2020). Additionally, Chen et al. (2016) provides empirical evidence to the failure of the critical mass theory by indicating that the involvement of even one female director within ACs could mitigate any potential 
for internal control weakness. Thus, the demographic attributes of the female directors rather than their mere involvement within the ACs may enhance the AC's monitoring role in the manner that may add some burden on external auditors to exert much time and effort to provide higher quality assurance and at the same time may expand the audit report timeliness.

Table 8: Additional Analysis: Number of female directors and ARL

\begin{tabular}{|c|c|c|c|c|}
\hline \multicolumn{5}{|c|}{ Panel A: Summary Statistics } \\
\hline $\begin{array}{l}\text { Variable } \\
\end{array}$ & Obs & Value & Freq. & Percent \\
\hline \multirow{2}{*}{ ONEFEM } & \multirow{2}{*}{633} & $\mathrm{o}$ & $37 \mathrm{I}$ & $58.6 \mathrm{I}$ \\
\hline & & $\mathrm{I}$ & 262 & $4 \mathrm{I} .39$ \\
\hline \multirow{2}{*}{ TWOFEM } & \multirow{2}{*}{633} & o & 413 & 65.24 \\
\hline & & $\mathrm{I}$ & 220 & 34.76 \\
\hline \multirow{2}{*}{ THREEFEM } & \multirow{2}{*}{633} & $\mathrm{o}$ & 580 & 91.63 \\
\hline & & $\mathrm{I}$ & 53 & 8.37 \\
\hline \multicolumn{5}{|c|}{ Panel B: Regression Results } \\
\hline Variables & \multicolumn{4}{|c|}{ Results } \\
\hline Independent Variables & \multicolumn{2}{|l|}{ Coef } & \multicolumn{2}{|c|}{$\mathbf{t}$} \\
\hline ACIND & \multicolumn{2}{|l|}{-5.78} & \multicolumn{2}{|c|}{$-1.76^{*}(0.08)$} \\
\hline ONEFEM & \multicolumn{2}{|l|}{1.29} & \multicolumn{2}{|c|}{0.67} \\
\hline TWOFEM & \multicolumn{2}{|l|}{-0.08} & \multicolumn{2}{|c|}{-0.04} \\
\hline THREEFEM & \multicolumn{2}{|l|}{5.01} & \multicolumn{2}{|c|}{$\mathrm{I} .8 \mathrm{I}^{*}(0.07)$} \\
\hline ACFEX & \multicolumn{2}{|l|}{0.06} & \multicolumn{2}{|c|}{$\mathrm{I} .43$} \\
\hline ACMET & \multicolumn{2}{|l|}{-18.23} & \multicolumn{2}{|c|}{$-1.56^{*}(0.10)$} \\
\hline ACSIZ & \multicolumn{2}{|l|}{-0.20} & \multicolumn{2}{|c|}{0.24} \\
\hline \multicolumn{5}{|l|}{ CONTROL VARIALES } \\
\hline $\mathrm{ROA}$ & \multicolumn{2}{|l|}{-24.55} & \multicolumn{2}{|c|}{-1.06} \\
\hline FSIZE & 0.30 & & & \\
\hline LEV & -I.03 & & & \\
\hline SUBSID & -O.OI & & & \\
\hline FYE & 3.13 & & 2.2 & o3) \\
\hline AUDTEN & -0.35 & & & \\
\hline AUDFEE & -3.84 & & -I.8 & o6) \\
\hline BODIND & -O.OI & & & \\
\hline BODFEM & 0.13 & & & \\
\hline BODSIZ & 0.39 & & & \\
\hline BODMET & 22.75 & & & \\
\hline BODFE & -0.02 & & & \\
\hline Constant & 26.52 & & & \\
\hline Year and Industry effect & & & rolled & \\
\hline Number of Obs. & & & 33 & \\
\hline P. Value & & & Doo & \\
\hline R-Squared & & & 38 & \\
\hline${ }^{* * *} \mathrm{p}<$. oI $,{ }^{* *} \mathrm{p}<.05,{ }^{*} \mathrm{p}<$ & & & & \\
\hline
\end{tabular}




\section{5-2 THE OVER-COMPLIANCE OF AC'S ATTRIBUTES AND ARL}

As mentioned before in section 3.I, FTSE 350 companies are more strictly adhering to UK CG code and also to the Smith Guidance. Regarding the AC' attributes, the recommendations stipulate a minimum level of adherence in relation to the AC's size; meeting and expertise possessed by its members. In this analysis, we examine the overcompliance of FTSE 350 companies' ACs that surpass the determined threshold and their effect on ARL to determine if there is any potential difference. Accordingly, we replace the following variables: ACFE; ACMEET and ACS by ACFE_D; ACMEET_D and ACS_D respectively. ACFE_D is a dummy variable that equals one if the AC has more than one financial expertise and zero otherwise. ACMEET_D is a dummy variable that take the value of one if the ACs' meeting is greater than three and zero otherwise. ACS_D is a dummy variable that take the value of one if the ACs' size is greater than three and zero otherwise.

Table 9. Additional Analysis: the AC' attributes over compliance and ARL

\begin{tabular}{|c|c|c|c|c|}
\hline \multicolumn{5}{|c|}{ Panel A: Summary Statistics } \\
\hline Variable & & Value & Frequency & percent \\
\hline \multirow{2}{*}{ ACFEX_D } & \multirow{2}{*}{63} & o & I4I & 22.27 \\
\hline & & I & 492 & 77.73 \\
\hline \multirow{2}{*}{ ACMET_D } & \multirow{2}{*}{63} & o & I5I & 23.85 \\
\hline & & I & 482 & 76.15 \\
\hline \multirow{2}{*}{ ACSIZ_D } & \multirow{2}{*}{63} & o & 168 & 26.54 \\
\hline & & I & 465 & 73.46 \\
\hline \multicolumn{5}{|c|}{ Panel B: Regression Results } \\
\hline \multicolumn{2}{|c|}{ Independent Variables } & Coef & \multicolumn{2}{|c|}{$\mathbf{t}$} \\
\hline \multicolumn{2}{|l|}{ ACIND } & -6.09 & \multicolumn{2}{|c|}{$-\mathrm{I.} .86^{*}(0.06)$} \\
\hline \multicolumn{2}{|l|}{ ACFEM } & 0.05 & \multicolumn{2}{|c|}{0.05} \\
\hline \multicolumn{2}{|l|}{ ACFEX_D } & $\mathrm{I} .45$ & \multicolumn{2}{|c|}{1.23} \\
\hline \multicolumn{2}{|l|}{ ACMEET_D } & .074 & \multicolumn{2}{|c|}{$2.07^{* *}(0.04)$} \\
\hline \multicolumn{2}{|l|}{ ACSIZ_D } & $-\mathrm{I} .22$ & \multicolumn{2}{|c|}{-0.87} \\
\hline \multicolumn{5}{|c|}{ Control Variables } \\
\hline \multicolumn{2}{|l|}{$\mathrm{ROA}$} & -22.02 & \multicolumn{2}{|c|}{-0.96} \\
\hline \multicolumn{2}{|l|}{ SIZE } & 1.56 & \multicolumn{2}{|c|}{0.6} \\
\hline \multicolumn{2}{|l|}{ LEV } & -5.30 & \multicolumn{2}{|c|}{-0.18} \\
\hline \multicolumn{2}{|l|}{ SUBSID } & -O.OI & \multicolumn{2}{|c|}{-0.83} \\
\hline
\end{tabular}




\begin{tabular}{|l|c|c|}
\hline FYE & 2.96 & $2.15^{* *}(0.03)$ \\
\hline AUDTEN & -0.28 & $-0.7 \mathrm{I}$ \\
\hline AUDFEE & -3.68 & $-\mathrm{I} .9^{*}(0.06)$ \\
\hline BODIND & -0.02 & -0.26 \\
\hline BODFEM & 0.15 & $\mathrm{I} .4$ \\
\hline BODS & 0.24 & 0.39 \\
\hline BODMET & 17.88 & 0.96 \\
\hline BODFEX & -0.03 & -0.35 \\
\hline Constant & 9.87 & 0.37 \\
\hline Year and Industry effect & & Controlled \\
\hline Number of Obs. & \multicolumn{2}{|c|}{633} \\
\hline P-Value & \multicolumn{2}{|c|}{0.000} \\
\hline R-Squared & \multicolumn{2}{|c|}{} \\
\hline${ }^{* * *} p<$. oI, ${ }^{* *} \mathrm{p}<.05,{ }^{*} \mathrm{p}<. \mathrm{I}$ & \\
\hline
\end{tabular}

Panel A, Table 9 shows that among all the 633 firm-year observations, nearly 78 percent appoint more than one financial expert in their ACs. In addition, more than three quarters ( 76 percent) of the sample observations meets more than three times a year and about 74 percent have ACs with more than three members. Panel $\mathrm{B}$, Table 9 present the regression results for the effect of the ACs' overcompliance to UK governance recommendation on ARL. The results are all in congruence with the results presented in the main analysis shown in Table 7.

\section{6- CONCLUSION}

Our paper investigates the effect of ACs' characteristics on audit report timeliness within the UK. Using a sample of 633 firm-year observations of companies listed on the FTSE 350 for 2017 to 2019, this study provides empirical evidence of the key determinants of ARL in relationship to ACs' attributes recommended by the UK CG code. Results reveal that ARL is a function of ACs' independence and activity. That is, the more the number independent non-executive members and the more the ACs' meeting, the shorter the ARL. In addition, the results also indicate that ARL is hardened to changes in ACs' gender, expertise and size. Furthermore, the companies' reporting period and the audit fees influence the audit report timeliness. The audits within the busy reporting period lead to more pressure on audit firms in a manner that leads to longer ARL. In addition, the higher the audit fees paid, the shorter the time to issue the audit report. 
Additional analysis reveals that large number of female directors in the ACs leads to longer lag periods between financial reporting date and auditors' signature date. Similar to Chen et al. (2016), our results are inconsistent with the critical mass theory that indicates that the potential effect of gender diversity is augmented when the number of female directors exceed certain threshold. Our results indicate that the mere representation of female directors within ACs might not matter, rather other attributes such as their education or expertise level may add value to their expected monitoring role. Additional analysis, based on the alternate measures of ACs' expertise, diligence and size, also confirms our main results.

The limitations of our research may open the door for other researcher for possible research avenues as follows. First, as mentioned earlier, compared to other listed UK companies, FTSE350 companies are subject to greater governance scrutiny. These special governance settings may limit the generalization of our results to less smaller companies. Thus, it would be interesting if future research examines the relationship between ARL and AC' attributes using a bigger sample that encompasses all listed UK companies. Second, the UK CG code stipulates that AC's members should possess experience in the industry field of their companies. Future research could examine the effect of industrial expertise of AC' members on lessening the lag period for the audit report. Third, our study focuses only on the association of ACs' attributes and ARL. Other research could examine the impact of the interlocking directorship for ACs' members on the audit report lag.

\section{REFERENCE}

Abbott, L. J.; Park, Y. and Parker, S. (200o). The effects of audit committee activity and independence on corporate fraud. Managerial Finance, 26 (II), 55-68. https://doi.org/10.IIo8/03074350010766990

Abbott, L. J.; Parker, S.; Peters, G. F. and Raghunandan; K. (2004) The Association between Audit Committee Characteristics and Audit Fees. Auditing: A Journal of Practice and Theory. 22(2), 17-32.

Abdelsalam, O. H. and Street, D. L. (2007). Corporate governance and the timeliness of corporate internet reporting by U.K. listed companies. Journal of International Accounting, Auditing and Taxation, I6(2), IIII3o. 
Abdillah, M. R.; Mardijuwono, A.W. and Habiburrochman, H. (2019). The effect of company characteristics and auditor characteristics to audit report lag. Asian Journal of Accounting Research, 4(I), I29I44. https://doi.org/I0.I108/AJAR-05-2019-0042

Abdullah, N. (2007). Board Composition, Audit Committee and Timeliness of Corporate Financial Reports in Malaysia. Corporate Ownership and Control, 4(2), 33-45.

Abernathy, J. L.; Beyer, B.; Masli, A. and Chad, S. (2014). The Association Between Characteristics of Audit Committee Accounting Experts, Audit Committee Chairs, And Financial Reporting Timeliness. Advances in Accounting, incorporating Advances in International Accounting, 30, 283-297.

Abood A.; Baatwah S. and Al-Musali, M. (2020). Religiosity, accounting expertise, and audit report lag: Empirical evidence from the individual level. Cogent Business and Management, 7:I, I823587, DOI: Io.1080/23311975.2020.1823587

Adams, R. and Ferreira, D. (2009). Women in the boardroom and their impact on governance and performance. Journal of Financial Economics. 94(2), 29I-309.

Afify, H. A. (2009). Determinants of audit report lag: Does implementing corporate governance have any impact? Empirical evidence from Egypt. Journal of Applied Accounting Research io (I), 56-86.

AIM Survey (2018). FTSE 350 and AIM Ioo auditors, Accountancy, March, www.accountancylive.com.

Alhadab, M. (2016). Auditor Report and Earnings Management: Evidence from FTSE 350 Companies in the UK. Risk Governance E\& Control: Financial Markets \& Institutions. 6(4), 334-344.

Al-Mulla, M. and Bradbury, M.E. (2020). The demand and supply timely financial reports. Pacific Accounting Review, 32(3), 335-353. https://doi.org/IO.IIO8/PAR-IO-2018-0076 
Al-Shaer, H. and Zaman, M. (2018). Credibility of Sustainability Reports: The contribution of Audit Committees. Business Strategy and The Environment. 27(7), 973-986.

Al-Shaer, H.; Salama, A. and Toms, S. (2017). Audit Committees and Financial Reporting Quality: Evidence from UK Environmental Accounting Disclosures. Journal of Applied Accounting Research.I8 (I), 2-2I.

Baatwah, S.R.; Salleh, Z. and Stewart, J. (2019). Audit committee chair accounting expertise and audit report timeliness: The moderating effect of chair characteristics. Asian Review of Accounting. 27 (2), 273-306. https://doi.org/Io.IIo8/ARA-I2-2017-0I90

Bager, A.; Roman, M.; Algelidh, M. and Mohammed, B. (2017). Addressing multicollinearity in regression models: a ridge regression application. Journal of Social and Economic Statistics, 6 (I): 3045 https://mpra.ub.uni-muenchen.de/id/eprint/8I390

Bamber, E. M.; Bamber, L.S. and Schoderbek, M.P. (1993). Audit structure and other determinants of audit report lag: an empirical analysis. Auditing: A Journal of Practice and Theory. $\mathrm{12}$ (I), $\mathrm{I}-23$.

Beasley, M. S.; Carcello, J.V.; Hermanson, D.R.; Neal, T.L. (2010) The Audit committee oversight Process. Contemporary Accounting Research. 26(I), 65-122 https://doi.org/I0.1506/car.26.I.3

Bédard, J.; Chtourou, S. M. and Courteau, L. (2004). The Effect of Audit Committee Expertise, Independence, and Activity on Aggressive Earnings Management. Auditing: A Journal of Practice ES Theory, September, 23(2), 13-35, DOI: I0.2308/aud.2004.23.2.13

Bhuiyan, M. B. and D'Costa, M. (2020). Audit committee ownership and audit report lag: evidence from Australia. International Journal of Accounting and Information Management. 28 (I): 96-I25. https://doi.org/Io.IIo8/IJAIM-o9-20I8-0IO7.

Bouaziz, D.; Salhi, B. and Jarboui, A. (2020) CEO characteristics and earnings management: empirical evidence from france, Journal of Financial Reporting and Accounting, I8 (I), 77- IIO. https://doi.org/Io.IIO8 /JFRA-OI-20I9-0oo 8 
Cadbury, A. (1992). Report of the Committee on the Financial Aspects of Corporate Governance. London: Financial Reporting Council, London Stock Exchange.

Chalu, H. (202I). Board characteristics, auditing characteristics and audit report lag in African Central Banks. Journal of Accounting in Emerging Economies. II(4), 578-609. https://doi.org/Io.IIo8/JAEE-09-2019-0173

Chan, K. H.; Luo, V. W. and Mo, L.L. (2016). Determinants and implications of long audit reporting lags: evidence from China. Accounting and Business Research, 46 (2): 145-166.

Chen, Y.; Eshleman, J. D. and Soileau, J. S. (2016). Board gender diversity and internal control weaknesses, Advances in Accounting, (33), II-I9.

Chouaibi, S.; Chouaibi, Y. and Zouari, G. (202I). Board characteristics and integrated reporting quality: evidence from ESG European companies. EuroMed Journal of Business, Vol. ahead-of-print No. ahead-of-print. https://doi.org/IO.IIO8/EMJB-II-202O-OI2I

Cohen, J.; Krishnamoorthy, G. and Wright, A. (2004). The corporate governance mosaic and financial reporting quality. Journal of Accounting Literature, (23), 87-152.

Combined Code (2003). The Combined Code on Corporate Governance, London: Financial Reporting Council.

Defond, M. L.; Hann, R.N. and Hu, X. (2005) Does the market value financial expertise on audit committees of boards of directors? Journal of Accounting Research. 43 (2):I53-193. doi.org/I0.IIII/j.I475-679x.2005. ooi66.x

DeZoort, F. T.; Hermanson, D. R.; Archambeault, D. S. and Reed, S. A. (2002). Audit committee effectiveness: A Synthesis of the empirical audit committee literature. Journal of Accounting Literature. (2I), 38-75.

Dhaliwal, D.; Naiker, V. and Navissi, F. (20I0). The Association Between Accruals Quality and the Characteristics of Accounting Experts and Mix of Expertise on Audit Committees. Contemporary Accounting Research, 27(3), 787-827 https://doi.org/Io.III/j.I9II-3846.2010. oIO27.x 
Durand, G. (2019). The determinants of audit report lag: a meta-analysis", Managerial Auditing Journal, 34 (I): 44-75. https://doi.org/Io.IIo8/ MAJ-o6-20I7-I572.

Elmagrhi, M. H.; Ntim, C. G.; Crossley R. M.; Malagila J. K.; Fosu S. and Vu, T. V. (2017) Corporate governance and dividend pay-out policy in UK Listed SMEs: the effects of corporate board characteristics, International Journal of Accounting and Information Management. 25 (4): 459-483. https://doi.org/IO.IIO8/IJAIM-02-2017-002O

Fama, E. F. and Jensen, M. C. (1983) Separation of ownership and control”, The Journal of Law and Economics. 26 (2): 30I-325. https://doi.org/ I0.1086/467037

Felo, A., Solieri, S. (2009) Are all audit committee financial experts created equally? International Journal of Disclosure Governance, 6:I50-166. https://doi.org/I0.I057/jdg.2008.25

Financial Reporting Council (2018), The UK corporate governance code, available at: https://www.frc.org.uk/getattachment/886d8c45-50ea-484I-95bo-d2f 4 f4806gaz/20I8-UK-Corporate-Governance-Code-FINAL.PDF

Fontaine, R.; Khemakhem, H. and Herda, D.N. (2016) Audit committee perspectives on mandatory audit firm rotation: evidence from Canada. Journal of Management and Governance, 20(3), 485-502.

Francis, B.; Hasan, I.; Park, J. C. and Wu, Q. (20I5) Gender Differences in Financial Reporting Decision Making: Evidence from Accounting Conservatism. Contemporary Accounting Research. 32(3), I285-13I8.

Gendron, Y. and Bedard, J. (2006). On the constitution of audit committee effectiveness, Accounting, Organizations and Society, 3I (3), 2II-239.

Ghafran, C. and O'Sullivan, N. (2017). The impact of audit committee expertise on audit quality: evidence from UK audit fees, The British Accounting Review, 49(6):578-593. https://doi.org/I0.I0I6/j.bar.2017 .09.008

Ghafran, C. and Yasmin, S. (2018) Audit Committee Chair and Financial Reporting Timeliness: A Focus on Financial, Experiential and Monitoring Expertise. International Journal of Auditing. 22(I), I3-24. 
Ghafran, C. and O'Sullivan (2017). The impact of audit committee expertise on audit quality: Evidence from UK audit fees. The British Accounting Review. 49(6), 578-593.

Ghaleb, B. A.; Qaderi, S. A.; Almashaqbeh, A. and Qasem, A. (202I) Corporate social responsibility, board gender diversity and real earnings management: The case of Jordan, Cogent Business and Management, 8:I, I883222, DOI: I0.1080/23311975.202I.1883222

Goodwin-Stewart, J. and Kent, P. (2006) Relation between external audit fees, audit committee characteristics and internal audit. Accounting and Finance, 46(3), 387-404://doi.org/I0.11I1/j.I467-629X.2006.oo174.X

Guidance on Board Effectiveness (2018). https://www.frc.org.uk/getattachment $161232 f 60-a 338$-47Ib-basa-bfed25219I47/20I8-Guidance-on-BoardEffectiveness-FINAL.PDF

Habbash, M. (20I2). Earnings Management, Audit Committee Effectiveness and The Role of Blockholders Ownership: Evidence from UK Large Firms. Journal of Governance and Regulation, I(4), IOO-II6.

Habbash, M.; Sindezingue, C. and Salama, A. (2013). The Effect of Audit Committee Characteristics on Earnings Management: Evidence from the United Kingdom. International Journal of Disclosure and Governance, I0: 13-38. doi: I0.I057/jdg.20I2.2

Habib, A. and Bhuiyan, M. (20II). Audit firm industry specialization and the audit report lag. Journal of International Accounting, Auditing and Taxation, 2O(I): 32-44, https://doi.org/Io.IoI6/j.intaccaudtax .2010.12.004

Habib, A.; Bhuiyan, M.; Huang, H.J. and Miah, M. S. (2019). Determinants of Audit Report Lag: A Meta-Analysis. International Journal of Auditing. 23(I), 20-44.

Higgs D. (2003). Review of the Role and Effectiveness of Non-Executive Directors. London: Department of Trade and Industry.

Jensen, H. L. and Tang, R. Y. (1993). Audits of collective bargaining. The Internal Auditor, 50(2), 37-42. 
Jensen, M. C. and Meckling, W. H. (1976). Theory of the firm: managerial behaviour, agency costs, and ownership structure, Journal of Financial Economics.3 (4), 305-360.

Kapoor, N. and Goel, S. (2019). Do diligent independent directors restrain earnings management practices? Indian lessons for the global world. Asian Journal of Accounting Research, 4 (I):52-69 https://doi.org/Io.IIo8/AJAR$\underline{\mathrm{IO}-2018-0039}$

Kayleen, K. and Harindahyani, S. (2019). The impact of audit committee's effectiveness, gender, and tenure on audit report lag: Indonesian Evidence. Proceedings of the Ist International Conference on Business, Law and Pedagogy, ICB, I3-I5 February 2019, Sidoarjo, Indonesia, DOI: Io.4108/eai.I3-2-2019.2286077

Knechel, W. R. and Sharma, D. S. (2012). Auditor-provided non-audit services and audit effectiveness and efficiency: evidence from pre- and post-SOX audit report lags. AUDITING: A Journal of Practice ES Theory. $3 \mathrm{I}(4)$ : 85-II4.https://doi.org/IO.2308/ajpt-IO298

Krishnan, G.; Visvanathan, G. (2008). Was Arthur Andersen different? Further evidence on earnings management by clients of Arthur Andersen. International Journal of Disclosure Governance, 5, 36-47 https://doi.org/Io.Io57/palgrave.jdg.2050072

Liu, Y.; Wei, Z. and Xie, F. (2014). Do women directors improve firm performance in China? Journal of Corporate Finance, (28), 169-184.

Loughran, T. and Mcdonald, B. (2020) Measuring firm complexity, SSRN Electronic Journal, I-32. http://dx.doi.org/10.2139/ssrn.3645372

Mangena, M. and Pike, R. (2005). The effect of audit committee shareholding, financial expertise and size on interim financial disclosures. Accounting and Business Research, 35(4), 327-349, doi.org/10.1080/oool4788.2005.9729998

Mathuva, D. M.; Tauringana, V. and Fredrick, J. O. (2019) Corporate Governance and The Timeliness of Audited Financial Statements: The Case of Kenyan Listed Firms., Journal of Accounting in Emerging Economies, 9(4), 473-50I. 
Merendino, A. and Melville, R. (2019) The board of directors and firm performance: empirical evidence from listed companies”, Corporate Governance: The International Journal of Business in Society, 19(3), 508551. https://doi.org/10.1108/CG-06-2018-02II

Nelson, S.P. and Shukeri, S. (20II) Corporate governance and audit report timeliness: evidence from Malaysia. Research in Accounting in Emerging Economies.II(I):Io8-I28.https://doi .org/Io.IIO8/SI479-356300oooIIoIo.

Nehme, R.; Assaker, G. and Khalife, R. (2015) Dynamics of audit lag - Board of directors and audit committees' effect. Corporate Ownership and Control. I2(3), 28I-294, DOI: I0.22495/cocvi2izc3pI

Ntim, Collins G. (2015) Board diversity and organizational valuation: Unravelling the effects of ethnicity and gender. Journal of Management and Governance.19(I), 167-195.

Oradi, J. and Izadi, J. (2020) Audit committee gender diversity and financial reporting: evidence from restatements. Managerial Auditing Journal. 35(I), 67-92. https://doi.org/Io.IIo8/MAJ-IO-2018-2048

Oussii, A. A. and Taktak, N.B. (2018) Audit committee effectiveness and financial reporting timeliness: the case of Tunisian listed companies. African Journal of Economic and Management Studies. 9 (I), 34-55.

Pomeroy, B. and Thornton, D. B. (2008) Meta-Analysis and the Accounting Literature: The Case of Audit Committee Independence and Financial ReportingQuality. https://www.academia.edu/37862939/Meta Analysis and the Accounting Literature The Case of Audit Committee Independence and Financial Reporting Quality?from=cover page

Powell, M. and Ansic, D. (1997). Gender differences in risk behaviour in financial decision-making: An experimental analysis. Journal of Economic Psychology, I8(6), 605-628.

PwC (2020). In Depth A Look at Current Financial Reporting Issues: Accounting Implications of The Effects of Coronavirus, Authored by Debell, Tony and Kalidas, Vikash, April, bttps://www.pwc.co.uk/services/riskassurance/insights/accounting-and-reporting-updates/accounting-forcovid-rg-in-your-financial-reporting--what-you-ne.html 
Raimo, N.; Vitolla, F.; Marrone, A. and Michele R. (202I) Do audit committee attributes influence integrated reporting quality? An agency theory viewpoint. Business Strategy and the Environment, 30 (I), 522-534.

Raweh, N. A.; Abdullah, A. A.; Kamardin, H. H. and Malek, M. (202I). Industry expertise on audit committee and audit report timeliness. Cogent Business and Management, 8:I, I920113, DOI: 10.1080/23311975 .2021.1920113

Salleh, Z.; Baatwah, S. R. and Ahmad, N. (2017). Audit Committee Financial Expertise and Audit Report Lag: Malaysia Further Insight. Asian Journal of Accounting and Governance, (8), 137-150.

Sellami, M. Y. and Cherif, I. (2020) Female audit committee directorship and audit fees. Managerial Auditing Journal, 35 (3), 398-428. https://doi.org/ IO.IIO8/MAJ-I2-20I8-2I2I

Schubert, R. (2006) Analysing and managing risks - on the importance of gender differences in risk attitudes, Managerial Finance, 32 (9), 706-715.

Singh, H. and Sultana, N. (20II) Board of Director Characteristics and Audit Report Lag: Australian Evidence. Corporate Board: Role, Duties and Composition, 7 (3), 38-5I.

Smith Report (2003). Audit Committees Combined Code Guidance. Report to the Financial Reporting Council. London: Financial Reporting Council.

Soyemi, K. A.; Sanyaolu. and Salawu, R.O. (2019). Corporate governance practices and external auditor' reporting lag in Nigeria. Accounting and Taxation Review, 3(4), I5-3I.

Sultana, N.; Singh, H. and Van der Zahn, J-L. W. M. (2015) Audit Committee Characteristics and Audit Report Lag. International Journal of Auditing. (19), 72-87 doi:Io.III//ijau.I2033

Sun, J.; Liu, G. and Lan, G. (20II) Does Female Directorship on Independent Audit Committees Constrain Earnings Management?. Journal of Business Ethics, 99:369-382.DOI I0.1007/sio55I-0I0-0657-0

Syofyan, E.; Septiari, D.; Dwita, S. and Rahmi, M. (202I) The characteristics of the audit committee affecting timeliness of the audit report in 
Indonesia, Cogent Business and Management, 8:I, 1935183, DOI: I0.1080/23311975.2021.1935183.

Tanyi; P. N. and Smith, D. (2015) Busyness, expertise, and financial reporting quality of audit committee chairs and financial experts. Auditing: $A$ Journal of Practice ES Theory. 34 (2): 59-89. https://doi.org /10.2308/ajpt-50929

The Smith's Guidance (2003). Audit Committees Combined Code Guidance A Report and Proposed Guidance. Financial Reporting Council. London. https://scholar.google.com/scholar lookup?title= Audit \%2ocommittee \%2ocombined\%2ocode\%2oguidanceand author= Smith\%2o Committeeand publication year $=2003$

UK Corporate Governance (CG) Code (2018). at https://www.frc.org.uk /getattachment/88bd8c45-50ea-484I-95bo-d2f4f48069a2/20I8-UKCorporate-Governance-Code-FINAL.PDF

Velte, P. (2018). Does gender diversity in the audit committee influence key audit matters' readability in the audit report? UK Evidence. Corporate Social Responsibility and Environmental Management. 25 (4), 748-755.

Velte, P. (2020). Associations between the financial and industry expertise of audit committee members and key audit matters within related audit reports. Journal of Applied Accounting Research. 2I(I):185-200. https:// doi.org/IO.IIO8/JAAR-IO-20I8-0I63.

Wan-Hussin, W. N. and Bamahros, H. M. (2013) Do investment in and the sourcing arrangement of the internal audit function affect audit delay?. Journal of Contemporary Accounting ES Economics, 9(I), I9-32.

Zaitul, Z. and Desi Ilona (2018) Gender in audit committee and financial reporting timeliness: the case of unique Continental European model. International Journal of Engineering and Technology. 7 (2.29):436-442 DOI: 10.I4419/ijet.v7i2.29.13668

Zalataa, A. M.; Tauringanaa, V. and Tingbanic, I. (2018) Audit committee financial expertise, gender, and earnings management: Does gender of the financial expert matter, International Review of Financial Analysis, $55,170-183$. 


\section{تأثير خصائص لجنة المراجعة على توقيت إصدار تقرير المراجعة : دراسة

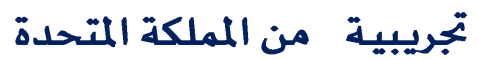

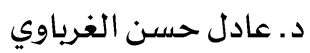 \\ د. ليلى محمد الشوادفي العدوي}

\section{ملخص البحث باللغة العربية}

تبحث هذه الدراسة علاقة الارتباط بين خصائص لجان المراجعة وإصدار تقرير المراجع في الوقت المناسب لكبري الشركات

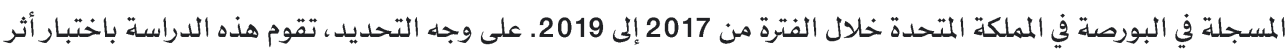

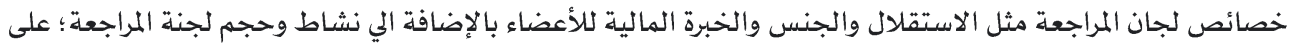

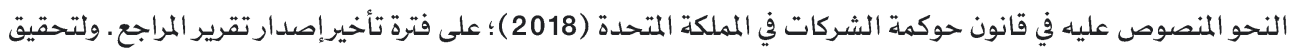

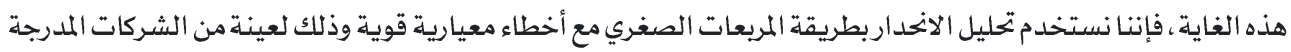
في مؤشر FTSE 350 على مدارثلاث سنوات بإجمالي عدد 633 مشاهدة.

تشير النتائج إلى أن استقلالية وتكرار اجتماعات لجان المراجعة مرتبطان بتقليل تأخيرتقرير المراجع الخاربي ـ ومع ذلك، تشير

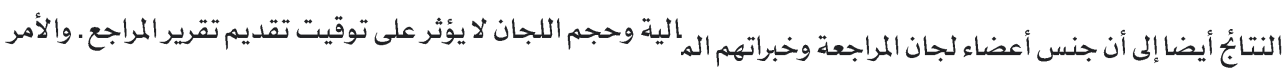

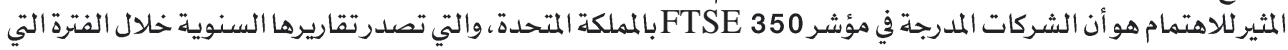

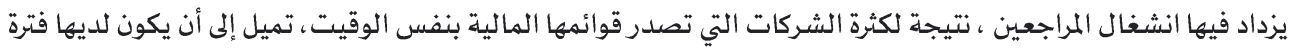

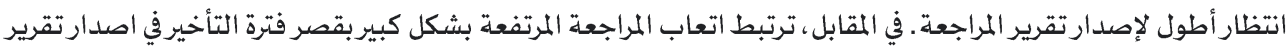
المراجع.

على عكس ما تقترحه نظرية الكتلة الحرجة، يكشف التحليل الإضافي أن التمثيل العالي للأعضاء الإناث في لجان المراجعة من شأنه أن يؤثر بالسلب علي توقيت إصدار التقارير المالية، نظرا لارتباطه بفترة أطول في تأخيرصدورتقرير المراجع. كما أن نتائج

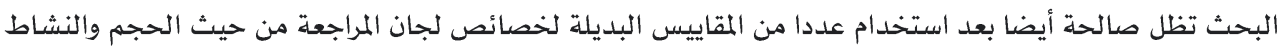

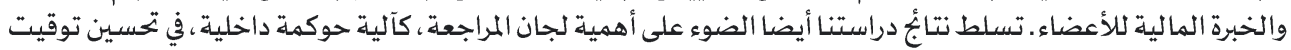

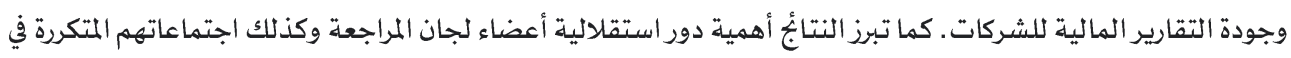

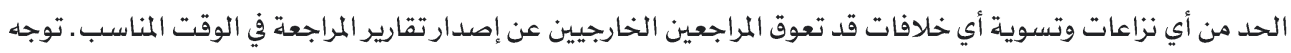

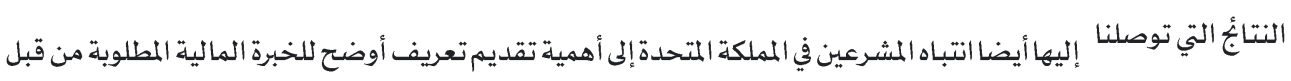

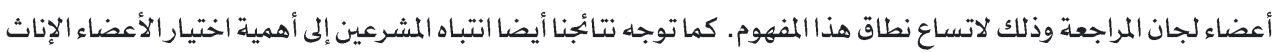

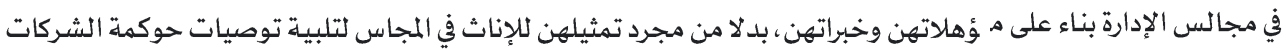
في المملكة المتحدة.

الكلمات الدالة : خصائص لجان المراجعة ، فترة تأخير إصدارتقرير المراجع، حوكمة الشركات، المملكة المتحدة، FTSE350

\section{Suggested Citation according to APA Style}

Aladwey, L.M.A.; Elgharbawy, A. H.(202I). The Effect of Audit Committee's Characteristtics on The Audit Report Timeliness: Empirical Evidence From the UK. Journal of Alexandria University for Administrative Sciences, Faculty of Commerce, Alexandria University 58(5),231-272.

All rights reserved (c) 2021 